University of Montana

ScholarWorks at University of Montana

8-1992

\title{
"Living Words": Samuel Taylor Coleridge and the Genesis of the OED
}

James C. McKusick

University of Montana - Missoula, mckusickj@umkc.edu

Follow this and additional works at: https://scholarworks.umt.edu/eng_pubs

Part of the English Language and Literature Commons

Let us know how access to this document benefits you.

\section{Recommended Citation}

McKusick, James C., "'Living Words": Samuel Taylor Coleridge and the Genesis of the OED" (1992).

English Faculty Publications. 6.

https://scholarworks.umt.edu/eng_pubs/6

This Article is brought to you for free and open access by the English at ScholarWorks at University of Montana. It has been accepted for inclusion in English Faculty Publications by an authorized administrator of ScholarWorks at University of Montana. For more information, please contact scholarworks@mso.umt.edu. 


\title{
"Living Words": Samuel Taylor Coleridge and the Genesis of the $O E D$
}

\author{
JAMES C. MCKUSICK \\ University of Maryland, Baltimore County
}

Today we are at a crucial moment in the evolution of the Oxford English Dictionary, as the dog-eared volumes are withdrawn from library shelves and replaced by the sleek second edition of 1989. This new $O E D$ bears witness to the continuing relevance and utility of the "New English Dictionary on Historical Principles" for the current generation of literary scholars. The event of its publication provides an opportunity for a fresh historical perspective on the circumstances surrounding the production of the original $O E D$, which was published between 1884 and 1928 in a series of 125 fascicles and bound up into those thick volumes so familiar to students and teachers of English literature. Indeed, the $O E D$ has become so familiar as an everyday reference work that we are apt to lose sight of its historical origin and, thus, of the ideological imperatives that are encoded in the very structure of its lexical entries. Underlying its overt commitment to scientific principles, the $O E D$ is very much the embodiment of a Romantic ideology of language, and the role of this ideology in its genesis and development needs to be more fully examined if we are to reach an adequate understanding of its catalytic role in the formation of high Victorian culture. ${ }^{1}$

The $O E D$ was the collaborative production of an international community of scholars working within a shared historical conception of

1. For the ideological conflict between the skepticism and materialism of the Neogrammarians and the Romantic idealism of the high Victorian philologists, see Linda Dowling, Language and Decadence in the Victorian Fin de Siècle (Princeton, N.J., 1986), pp. xiii-xv, 3-103. On the role of Victorian ideology in the study of language, see Hans Aarsleff, From Locke to Saussure: Essays on the Study of Language and Intellectual History (Minneapolis, 1982), pp. 31-41, and "Joseph de Maistre and Victorian Thought on the Origin of Language and Civilization," in Studies in the History of Western Linguistics, ed. Theodora Bynon and F. R. Palmer (Cambridge, 1986), pp. 96-108. 
language and a common dedication to the notions of science and progress. The most advanced scientific ideas and technologies of the Victorian era contributed to the production of the $O E D$, most notably the introduction of steamships and railways, which allowed rapid and dependable communication among scholars, and new advances in typesetting which enabled the accurate and efficient publication of dictionary fascicles embodying multiple typefaces and nonstandard alphabets. The famed Scriptorium where James Murray assembled the dictionary was itself an embodiment of the latest technology, constructed of corrugated iron as a precaution against fire. ${ }^{2}$ The single most innovative feature of the $O E D$ is its use of illustrative quotations arranged chronologically to show the historical cvolution of each word. This technical innovation, first proposed by Franz-Passow in 1812 and exemplified in the Greek-English Lexicon of Liddell and Scott (1843), was adopted for the OED as the result of a new "scientific" understanding of language that first became prevalent among British scholars during the Victorian period. ${ }^{3}$ In contrast to the essentially normative and synchronic conception of language that prevailed during the Enlightenment and received its canonical expression in Samuel Johnson's Dictionary (1755), the OED is founded on a conception of language that is essentially descriptive and historical, regarding each word as the result of an evolutionary process that has continued from the earliest recorded period of the English language up to the present day. ${ }^{4}$ The $O E D$ does not, for the most part, presume to discriminate between "refined" and "vulgar" usage: it simply

2. K. M. Elisabeth Murray, Caught in the Web of Words: James Murray and the Oxford English Dictionary (Oxford, 1977), p. 172.

3. The first editor of the OED stated that "the theory of lexicography we profess is that which Passow was first to enunciate clearly and put in practice successfully-vis... 'that every word should be made to tell its own story' - the story of its birth and life, and in many cases of its death, and even occasionally of its resuscitation" (Herbent Coleridge. "A Letter to the Very Rev. The Dean of Westminster, 30 May 1860 ." printed as an appendix to Richard $\mathrm{C}$. Trench, "On Some Deficiencies in Our English Dictionaries," Transactions of the Philological Society [1857], pt. 2. p. 72). Other models for the historical method and typographic design of the OED include Jacob (imm and Wilhelm Grimm, Deutsches Wörterbuch (Leipzig, 1854-1954); and Émile I iture. Dirtionnaire de la langue frangaise (Paris, 1873-74). Sec also K. M. E. Murrav, pp. 135-36, 150-51; and Hans Aarsleff, The Study of Language in England, 1780-1860) (Princetom, N.J., 1967), pp. 252-57.

4. Samuel Johnson's Dictionary is contrasted with the OED in James A. H. Murrat. The Exolution of English Lexicography (Oxford, 1900), pp. 38-49. For the philosophical hasis of Johnson's lexicography, see Elizabeth Hedrick, "Locke's Theory of Language and Johnson's Dictonary." Eighteenth-Century Studies 20 (1987): 422-44. See also Allen H. Reddick, The Making of Johnson's Dictionary, 1746-1773 (Cambridge, 1990 . 
attempts to record the facts of linguistic history as fully and as accurately as its source materials allow. 5

This evolutionary conception of language became so widely diffused during the latter part of the nineteenth century that its point of origin seems almost impossible to determine. We might describe it as just another manifestation of the ubiquitous historicism of the Victorian outlook, a worldview that also informed the evolutionary theory of Charles Darwin and the economic determinism of Karl Marx. The $O E D$ is just as much a product of its intellectual climate as The Origin of Species or Das Kapital, those other Victorian books that seek to explain the origin of everything. In the case of the $O E D$, however, it seems possible to identify with some precision the main intellectual sources of its rationale and methodology. These sources have been carefully investigated by Hans Aarsleff, who convincingly demonstrates that the $O E D$ could only have been conceived within the context of the new philology imported to England from Germany and Denmark during the mid-nineteenth century. ${ }^{6}$ This new philology, contained in the work of such linguists as Friedrich Schlegel, Franz Bopp, Jacob Grimm, and Rasmus Rask, was grounded in the historical study of Germanic languages within the larger context afforded by the discovery of Sanskrit and the systematic development of the Indo-European hypothesis of linguistic origin. Aarsleff describes how a small community of British scholars, working largely outside the traditional academic framework, became acquainted with the methods of the new Germanic philology and began to apply them to the study of the early development of English. These dedicated scholars founded the Philological Society of London, published a series of early English texts, and devoted themselves to the task of collecting quotations for a new English dictionary.

This remarkable increase of philological activity during the midnineteenth century invites broader analysis of its social and ideological context. Why did this motley group of lawyers, schoolteachers, clergymen, and aristocratic dilettantes coalesce around such an

5. Aside from its omissions due to gaps in its documentation and its systematic exclusion of proper names and words obsolete before 1250, the OED reveals some ideological bias in its treatment of certain types of vocabulary. The OED incompletely represents certain lexical categories: scientific and technical terms, informal and colloquial English (especially sexual slang), dialect and regional English, and nonce words and hapax legomena. Although Victorian reviewers frequently criticized the $O E D$ for including too many abstruse or "vulgar" words, modern readers are more often surprised at the extent of its omissions (especially in the early volumes). Many of these lexical gaps are now filled by the new $O E D$, especially for the post-1800 period.

6. Aarsleff, The Study of Language in England, pp. 211-63. 
unlikely project as a new English dictionary? What was the common inspiration behind their diverse intellectual activities? Richard Bailey has remarked upon the unique social conditions that made possible the production of the $O E D$ by hundreds of amateur philologists: "The $O E D$, like the editions of the nineteenth-century text societies upon which it relies, is thus in part the product of a large, educated leisure class well-disposed toward literary and linguistic research and willing to devote extraordinary efforts to a collective project."7 Only during the Victorian period could such a project have drawn upon a distinct social group trained in philological methods and willing to devote substantial amounts of time and effort to literary research. The production of the $O E D$ was greatly facilitated by the formation of this new social group, which owed its existence partly to a restructuring of British educational institutions that enabled the broad dissemination of philological knowledge, and partly to the development of a compelling rationale for the historical study of language.

Throughout the nineteenth century, the industrial revolution provided the economic basis for an enormous increase in the number of "men of letters" (and women of letters) both within and outside the British universities. ${ }^{8}$ It was Samuel Taylor Coleridge who first named this professional intellectual class the "clerisy," signaling their new self-awareness as a social group and contributing to their sense of collective mission and national leadership. ${ }^{9}$ In particular, Coleridge's

7. Richard Bailey et al., Michigan Early Modern English Materials (Ann Arbor, Mich., 1975), p. xxv.

8. The restructuring of British education in the nineteenth century involved the founding of new universities (such as the University of London, headquarters of the Philological Society) and the opening of higher education to previously marginal groups (including dissenters, ethnic minorities, and women). As a Scottish Congregationalist, James Murray always felt excluded from the academic life of Oxford University, and he did much to open the $O E D$ to the participation of "outsiders" like W. C. Minor, a talented American reader who was an inmate in the Broadmoor Criminal Lunatic Asylum. Murray's coeditor Frederick J. Furnivall did much to promote the education of working-class men and women (K. M. E. Murray, pp. 88, 305-7). The role of women in the production of the $O E D$ would be a fascinating subject for further research, particularly in the larger context of the dictionary's role as a catalyst for the emerging social identity of the clerisy. Women were involved in all stages of production, especially as readers and subeditors.

9. Coleridge first defined the term "clerisy" in On the Constitution of Church and State (1830), new ed. (Princeton, N.J., 1976), p. 46: "The clekisy of the nation . . comprehended the learned of all denominations; - the sages and professors of the law and jurisprudence; of medicine and physiology; of music; of military and civil architecture; of the physical sciences; with the mathematical as the common organ of the preceding; in short, all the so-called liberal arts and sciences, the possession and 
seminal remarks on the history of language provided an ideological foundation for the rebirth of philology in England. Coleridge played a crucial role in the origin of the $O E D$, since he first imagined the possibility of such a dictionary and fostered the intellectual and social conditions necessary for its production. As a spokesman for the newly emerging clerisy, Coleridge frequently advocated the study of early English texts, and his writings introduced an entire generation of British and American readers to the insights offered by the new Germanic philology. Coleridge thus contributed largely to the cultural situation in which hundreds of amateur philologists were willing to labor in relative anonymity toward the construction of a vast new historical dictionary.

Coleridge was intellectually well equipped to be an advocate for the new Germanic philology. From an early age he was fascinated by the history of language, and in 1798 he traveled to Germany to learn more about the exciting new developments there. For several months, Coleridge was enrolled in the University of Göttingen, which was known as a leading center of philology and biblical hermeneutics. After mastering the German language, Coleridge began to study the older Germanic dialects; these soon became a consuming interest to him, no doubt as a result of the inspiring example of the great philologists then at work in Göttingen. Foremost among these was Christian Gottlieb Heyne, whom Coleridge describes as "the HeadLibrarian at Göttingen, \&, in truth, the real Governor of Göttingen." 10 Heyne's classical scholarship enjoyed immense prestige and authority among his colleagues; he was largely responsible for the "philological explosion" in the German academy. ${ }^{11}$ Through Heyne, Coleridge is likely to have been exposed to the thought of Herder in all of its deep, even mystical, historicism and its concern for the remote origins of the Greek and Germanic cultures. Coleridge's professors at the University of Göttingen also included Johann Gottfried Eichhorn,

application of which constitute the civilization of a country, as well as the Theological." On the role of the clerisy in establishing and propagating the national language, see Dowling ( $\mathrm{n} .1$ above), pp. 28-29. See also Ben Knights, The Idea of the Clerisy in the Nineteenth Century (Cambridge, 1978).

10. Collected Letters of Samuel Taylor Coleridge, ed. Earl L. Griggs, 6 vols. (Oxford, 1956-71), 1:472; hereafter cited in the text as Letters.

11. On Heyne's crucial role in the emergence of Germanic philology, see Robert S. Leventhal, "Language Theory, the Institution of Philology and the State: The Emergence of Philological Discourse, 1770-1810," Studies in the History of the Language Sciences 38 (1987): 349-59. Heyne's accomplishments became widely known in England during the early Victorian period, partly as a result of Thomas Carlyle's essay "The Life of Heyne," first published in the Foreign Review, vol. 4 (1828). 
a controversial figure who was the leading exponent of the Higher Criticism (a new historically oriented textual analysis of the Bible). Another important influence on Coleridge was Georg Friedrich Benecke, a professor of English and German philology who was later called the "father of Germanistik." 12 Benecke instructed Coleridge in the history of the German language in the Middle Ages, beginning with Faust and Nathan, and finishing with the Nibelungenlied.

Coleridge was sufficiently inspired by the example of Benecke and his fellow philologists that he planned to follow in their footsteps. He told his friend Thomas Poole that he meant to write a book on philological topics: "Therefore at the end of two or three years if God grant me life expect to see me come out with some horribly learned book, full of manuscript quotations from Laplandish and Pathagonian authors-possibly, on the striking resemblance of the Sweogothic \& Sanskrit languages, \& so on" (Letters 1:494). Coleridge's offhand suggestion of a connection between Gothic and Sanskrit seems to indicate that he was conversant with Sir William Jones's recent discovery of Sanskrit and his development of the Indo-European hypothesis, subjects that were being widely debated throughout the German academy at this time, though largely ignored in England. By the time of his departure from the University of Göttingen in April 1799, Coleridge had evidently gained a wide familiarity with the kind of research being done in contemporary linguistics and, perhaps more important, a sense of the boundless enthusiasm that accompanied the early development of Germanic philology.

After his return to England, Coleridge continued to develop his plan for a treatise on the evolution of language. In September 1800 , he wrote a letter to William Godwin that outlined the kind of work he contemplated:

I wish you to write a book on the power of words, and the processes by which human feelings form affinities with them-in short, I wish you to philosophize Horn Tooke's System, and to solve the great

Questions-whether there be reason to hold, that an action bearing all the semblane of pre-designing Consciousness may yet be simply organic, \& whether a series of such actions are possible-and close on

12. Coleridge describes his studies at the University of Goutingen in the Biographia Literaria, ed. James Engell and W. Jackson Bate, 2 vols. (Princeton, N.J., 1983), 1:206-9. Coleridge mentions his acquaintance with Eichhorn in Letters, 1:494. On Bcnecke's influence and reputation, see I.. A. Willoughby, "Coleridge as a Philologist," Modern Language Review 31 (1936): 180; and Aarsleff, The Study of Language in Iingland. Pp. $178-79$. 
the heels of this question would follow the old "Is Logic the Essence of Thinking?" in other words-Is thinking impossible without arbitrary signs? \&-how far is the word "arbitrary" a misnomer? Are not words \&c parts \& germinations of the Plant? And what is the Law of their Growth? - In something of this order I would endeavor to destroy the old antithesis of Words E Things, elevating, as it were, words into Things, \& living Things too. [Letlers 1:625-26]

Coleridge alludes here to the etymological theories of John Horne Tooke, a famous contemporary linguist who attempted to trace all words back to a few simple roots designating perceptual objects, or what Locke termed "sensible ideas." 13 Prominent among the intriguing but rather obscurely expressed ideas in this letter is the notion that language forms an integrated organic system, "parts \& germinations of the Plant," not merely an atomistic nomenclature of arbitrary signs (as Locke's conception of language implied). Coleridge's description of words as "living Things" has important consequences for the empirical study of language, since it implies that etymology must be studied through the systematic perspective of comparative grammar rather than on an ad hoc, piecemeal basis (as Horne Tooke tended to do). Long before any of his contemporaries, Coleridge clearly realized the need to acquire the tools of the new Germanic philology; in a letter of December 1800 , he claims to be studying "the Northern Languages, the Sclavonic, Gothic \& Celtic, in their most ancient forms" (Letters 1:656). In 1803 he rather ambitiously describes his intended treatise as a "philosophical Romance to explain the whole growth of Language."14 By February 1808, he confidently claims to possess "many a scrap, illustrating the laws by which Language would polypize ad infinitum-and a compleat History of it's [sic] original formation" (Letters 3:58). Coleridge's notebooks from this period are full of such "scraps" illustrating the etymology and usage of English words, usually in the form of quotations drawn from his wide and omnivorous reading, an early foreshadowing of the millions of citation slips that would eventually be gathered for the $O E D$.

As Coleridge gathered the materials for his intended treatise on language, he became ever more acutely aware of the inadequacies of

13. Horne Tooke's theory, influence, and reputation are described by Aarsleff, The Study of Language in England (n. 3 above), pp. 44-114. For Coleridge's response to Horne Tooke, see my Coleridge's Philosophy of Language (New Haven, Conn., 1986), pp. 33-52.

14. The Notebooks of Samuel Taylor Coleridge, ed. Kathleen Coburn, 4 vols. to date (Princeton, N.J., 1957-), 1:1646; hereafter cited as Notebooks. 
existing English dictionaries and the need for a new dictionary that would reflect the latest philological discoveries. In the Biographia Literaria (1817), he sternly denounced Samuel Johnson's dictionary (which was still generally regarded as the highest authority on correct English usage) on the grounds of its incompleteness and inaccuracy. ${ }^{15}$ Coleridge issued his own proposal for a new English dictionary embodying the latest findings in comparative and historical linguistics: "Were I asked, what I deemed the greatest and most unmixt benefit, which a wealthy individual, or an association of wealthy individuals could bestow on their country and on mankind, I should not hesitate to answer, 'a philosophical English dictionary; with the Greek, Latin, German, French, Spanish and Italian synonimes, and with correspondent indexes. " 16 In the following year, Coleridge entered into a contractual agreement with the publishers of the Encyclopedia Metropolitana to prepare an etymological dictionary of the English language. Coleridge described the plan for this new dictionary in terms that strikingly foreshadow the OED: each word would be accompanied by illustrative citations in chronological order, with "every attention to the independent beauty or value of the sentences chosen ... consistent with the higher ends of a clear insight into the original and acquired meaning of every word." 17 His main intention in this project was to include the numerous words left out of Johnson's dictionary while also providing more complete historical documentation for each word. Coleridge's historical approach to lexicography became even more explicit in his manuscript treatise Logic (written in the 1820s), which called "for a dictionary constructed on the only philosophical principle, which regarding words as living growths, offlets, and organs of the human soul, seeks to trace each historically through all the periods of its natural growth and accidental modifications." 18

Like so many of Coleridge's overly ambitious projects, this dictionary was never completed, and eventually it fell into the less capable hands of Charles Richardson, who published his New Dictionary of the English Language in 1836-37. Richardson's dictionary was perhaps an improvement on Johnson's in its inclusion of copious citations arranged in chronological order, but it fell short of the high goals that

15. Biographia Literaria, 1:239n.

16. Ibid., $1: 239$ n.

17. Samuel Taylor Coleridge's Treatise on Method as Published in the Encyclopaedia Metropolitana, ed. Alice D. Snyder (London, 1934), facing p. 71.

18. Logic, ed. J. R. de J. Jackson (Princeton, N.J., 1981), p. 126. Coleridge further describes his plan for a new English dictionary in his Philosophical Lectures, ed. Kathleen Coburn (London, 1949), pp. 173-74. 
Coleridge had set for his own project, especially in its almost total ignorance of the new Germanic philology. ${ }^{19}$ Yet Coleridge's dream of a new English dictionary lived on in the minds of his younger contemporaries, many of whom remembered his call for a new dictionary and cherished his inspiring remarks on the fundamental knowledge revealed in the history of words. Among these admirers of Coleridge was Ralph Waldo Emerson, who made a pilgrimage to visit him at Highgate in 1832, and who later developed an essentially Coleridgean view of language in the fourth chapter of Nature (1836), especially in his assertion of a symbolic correspondence between words and natural objects and his view of etymology as containing deep moral and intellectual truths. ${ }^{20}$

Also prominent among Coleridge's admirers was Julius Charles Hare, Coleridge's occasional visitor at Highgate during the 1820 s and a lifelong advocate of his views in philosophy, politics, and theology. ${ }^{21}$ For many years Hare was a close friend and associate of Connop Thirlwall, who served as president of the Philological Society of London from its founding in 1842 until 1868; they both attended Trinity College, Cambridge (1814-18) and returned there to collaborate on a translation of B. G. Niebuhr's History of Rome from the German (182832). Hare and Thirlwall were both members of the Cambridge Apostles' Club, a group described by its leader, Frederick Denison Maurice, as "a small society... which defended Coleridge's metaphysics and Wordsworth's poetry against the utilitarian teaching." 22 During the early 1830s, Hare and Thirlwall formed the Etymological Society at

19. On Charles Richardson, see Aarsleff, The Study of Language in England, pp. 24952; and James Murray (n. 4 above), pp. 44-45.

20. The fourth chapter of Emerson's Nature, entitled "Language," concludes with a quotation from Coleridge's Aids to Reflection (London, 1825; first American ed., Burlington, Vt., 1829), p. 150: "Every object rightly seen, unlocks a new faculty of the soul." See also Anthony J. Harding, "Coleridge and Transcendentalism," in The Coleridge Connection, ed. Richard Gravil and Molly Lefebure (London, 1990), pp. 233-53; and Philip F. Gura, The Wisdom of Words: Language, Theology, and Literature in the New England Renaissance (Middletown, Conn., 1981). David Simpson scrutinizes Transcendentalist theories of language in The Politics of American English, 1776-1850 (Oxford, 1986), pp. 230-59.

21. For the personal and intellectual relationship between Coleridge and Julius Hare, see Charles Richard Sanders, Coleridge and the Broad Church Movement (Durham, N.C., 1942), pp. 123-46. Sanders describes Hare's collaboration with Connop Thirlwall, pp. 123-26.

22. The Life of Frederick Denison Maurice, ed. Frederick Maurice (London, 1884), p. 174, cited by Robert O. Preyer, "The Romantic Tide Reaches Trinity: Notes on the Transmission and Diffusion of New Approaches to Traditional Studies at Cambridge, 1820-1840," in Victorian Science and Victorian Values: Literary Perspectives, ed. James Paradis and Thomas Postlewait (New York, 1981), p. 45. 
Cambridge, an informal association of about twenty scholars interested in classical and modern philology, particularly "the discoveries that have been made, of late years by the scholars upon the Continent." ${ }^{23}$ A major objective of this society was to publish "a new Etymological Dictionary of the English language; of which one main feature was to be that the three great divisions of our etymologies, Teutonic, Norman, and Latin, were to be ranged under separate alphabets"; but this project never got beyond the early planning stages. ${ }^{24}$ Several members of the Etymological Society contributed to the Philological Museum (1832-33), a short-lived periodical coedited by Hare and Thirlwall that published several important articles on the new philology, including the first English exposition of Grimm's analysis of the Germanic verb. ${ }^{25}$ This ferment of philological activity at Cambridge was inspired and organized largely by Hare and Thirlwall, and its central project - a dictionary incorporating the etymological discoveries of the new Germanic philology - was essentially an updated version of the lexicographic scheme first proposed by Coleridge in the Biographia Literaria. ${ }^{26}$

Julius Hare did much to popularize Coleridge's linguistic theories during the early Victorian period, particularly in his best-selling book, Guesses at Truth (1827), written in collaboration with his brother, Augustus Hare. This engaging collecting of aphorisms and short essays frequently refers to Coleridge's views on language and literature, singling out for special praise his ability to invent new words:

And they who have been students thus to purify their native tongue, may also try to enrich it. When any new conception stands out so boldly and singly as to give it a claim for a special sign to denote it, if no new word for the purpose can be found in the extant vocabulary of the language, no old word which, with a slight clinamen given to its meaning, will answer the purpose, they may frame a new one... Of

23. Philological Museum 1 (1832): 150, cited by Aarsleff, The Siudy of Language in Lingland (n. 3 above), p. 220. Aarsleff demonstrates the relevance of these philological activities at Cambridge to the early conception of the $O E D$, observing that seven members of the Etymological Society, including Hare and Thirlwall, kater joined the Philological Society of London in 1842.

24. William Whewell, letter published in Proceedings of the Philological Society of Lomdon 5 (1852): 142, cited by Aarsleff, The Study of Language in England, p. 217.

25. Philological Museum 2 (1833): 373-88, cited by Aarsleff, The Study of Language in England, p. 220.

26. Coleridge may have discussed this dictionary project, among other philological topics, during his 1833 visit to Cambridge as a guest of Thirlwall. See The Life of Sir William Rowan Hamilton, ed. R. P. Graves, 3 vols. (London, 1882-89), 1:601. 
this duty no Englishman of our times has shown himself so aware as Coleridge: which of itself is a proof that he possessed some of the most important elements of the philosophical mind. Nor were his exertions in this way unsuccessful. Several words that he revived, some that he coined, have become current, at least among writers on speculative subjects: and many are the terms of our philosophical vocabulary ... which he has stamped afresh, so that people begin to have some notion of their meaning. ${ }^{27}$

As an example of Coleridge's talent for innovation, the Hare brothers mention that his word "to desynonymise . . is a truly valuable one, as designating a process very common in the history of language, and bringing a new thought into general circulation." 28 This particular term, which was first published in the Biographia Literaria and more widely popularized by the Hare brothers, came to be commonly used by the early editors of the $O E D$. Frederick James Furnivall, for instance, argues that the new English dictionary should record all variant forms of a word, in order "that others coming after might see which prevailed, or whether both continued to exist, becoming desynonymized or not. If an Editor did not like them, he might add some note of his dissent, but should not exclude them." ${ }^{29}$ Furnivall appeals for the inclusion of variant forms, even those without apparent significance, as a way of preserving what Coleridge once described as the "reversionary wealth of our mother-tongue." 30 The Canones Lexicographici; or Rules to be Observed in Editing the New English Dictionary (compiled in 1859-60) also advise the editors to include "the Synonyms or Quasi-synonyms of the word, such as Fatherly, Fatherlike, \&c., for Paternal, \&c., with the view of showing, by contrast, the minuter shades of difference, which, to a native, at once distinguish them from each other, and determine the appropriateness of their employment in each particular case, or, in one word, of 'desynonymizing' them." ${ }^{31}$ In this way, Coleridge's notion of desynonymization

27. Augustus J. Hare and Julius C. Hare, Guesses at Truth by Two Brothers, Two Series in One Volume (reprint, London, 1905), p. 191. This popular work, frequently republished throughout the Victorian period, also discusses Coleridge's notion of the "organic whole" in Shakespearian criticism (pp. 157-63), his coinage of the word 'esemplastic' (p. 178), and his use of 'untranslatableness' as a criterion of style (p. 185).

28. Ibid., p. 178.

29. Frederick James Furnivall, "Response" to Herbert Coleridge, "On the Exclusion of Certain Words from a Dictionary," both in Transactions of the Philological Society (1860-61), pp. 43-44.

30. Biographia Literaria (n. 12 above), 1:86n.

31. Herbert Coleridge et al., Canones Lexicographici (London, 1861), last addendum to Transactions of the Philological Society 10 (1857): 6 . See further $n$. 46 below. 
came to justify the $O E D$ 's broad inclusion of variant forms and its careful discrimination of closely related words and senses. ${ }^{32}$

Perhaps the most important of these younger admirers of Coleridge in the later history of the $O E D$ was Richard Chenevix Trench, a graduate of Trinity College, Cambridge (1829) and a close associate of Hare and Thirlwall. Trench visited Coleridge in 1832 and had a lively discussion with him on issues of biblical criticism. ${ }^{33}$ During the 1840s Trench also became acquainted with Sara Coleridge, the daughter of Samuel Taylor Coleridge and (together with her husband, Henry Nelson Coleridge) the main editor of his works and guardian of his posthumous reputation. ${ }^{34}$ As a member of the Coleridge circle, Trench was fully conversant with his works and deeply influenced by his ideas on the history of language. In 1851, Trench recalled how, as a young man, he was affected by Coleridge's ideas on the study of language:

For many a young man "his first discovery that words are living powers, has been like the dropping of scales from his eyes, like the acquiring of another sense, or the introduction into a new world"while yet all this may be indefinitely deferred, may, indeed, never find place at all, unless there is some one at hand to help for him and to hasten the process; and he who does, will for ever after be esteemed by him as one of his very foremost benefactors. . . And they were not among the least of the obligations which the young men of our time owed to Coleridge, that he so often himself weighed words in the balance, and so earnestly pressed upon all with whom his voice went for anything, the profit which they would find in so doing. ${ }^{35}$

32. Coleridge first uses 'desynonymization' in a notebook entry of 1803 (Notebooks [n. 14 above], $1: 1336$ ) and first uses 'desynonymize' in an entry of 1805 (Notebooks, 2:2432). On the role of desynonymization in the historical evolution of language, see Biographia Literaria, 1:82-87.

33. Trench and his friend John Sterling visited Coleridge at Highgate in 1832. During this visit, Coleridge argued that "the Book of Daniel was written in the time of the Maccabees" (as do modern biblical scholars, drawing upon the findings of the Higher Criticism). According to Trench, "Sterling ... was quite convinced by his arguments; me he did not shake in the slightest degree" (Richard Chenevix Trench, Archbishop: Letters and Memorials, ed. Maria Trench, 2 vols. [London, 1888], 1:124). This self-portrayal of the young, orthodox Trench defying heresy is perhaps somewhat overdrawn.

34. Carlyle mentions that Trench and Sara Coleridge both attended one of his parties, apparently in or around 1843-44; see J. Bromley, Man of Ten Talents: A Portrait of Richard Chenevix Trench, 1807-86: Philologist, Poet, Theologian, Archbishop (Iondon, 1959), p. 81. Carlyle had also met S. T. Coleridge on various occasions and described their encounters in his Life of John Sterling (London, 1851), pt. 1, chap. 8.

35. Richard Chenevix Trench, On the Study of Words: Five Lectures (1851), reprinted together with English Past and Present: Five Lectures (1855), ed. George Sampson (London and Toronto, [1927]), pp. 3-4. 
Trench alludes here to Coleridge's statement, in Aids to Reflection (1825), that, "if words are not THINGs, they are LIVING POWERS, by which the things of most importance to mankind are actuated, combined, and humanized." 36 For Trench, as for Coleridge, words are not mere utilitarian objects but vital agents in the evolution of human culture. This conception of language provides an important rationale for philological research during the Victorian period, since it implies that the study of language can convey deep knowledge of history and human nature.

Coleridge more fully develops this view of language in his preface to Aids to Reflection, using the suggestive but somewhat reductive theories of Horne Tooke as a starting point for his own organic conception of language: "Horne Tooke entitled his celebrated work, "E $\varepsilon \varepsilon \alpha$

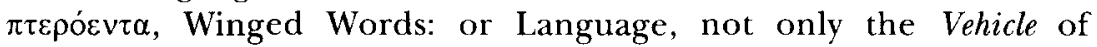
thought but the Wheels. With my convictions and views, for $\tilde{\varepsilon} \pi \varepsilon a$ I

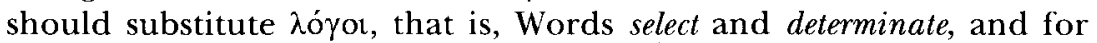
$\pi \tau \varepsilon \rho \operatorname{\varepsilon v} \tau \alpha \zeta \zeta_{0} \tau \varepsilon \varepsilon$, that is, living Words." 37 Words, for Coleridge, are "the Wheels of the Intellect," cognitive structures integral to all activities of the human mind. ${ }^{38}$ According to this view, language is a living organism because it is permeated with the creative energy of the poetic imagination, historically revealed in the seemingly inexhaustible generation of new lexical forms and their gradual semantic differentiation through the process of desynonymization. Coleridge's organic conception of language is well summarized by one of Humboldt's famous pronouncements: "Language is not a product (ergon) but an activity (energeia). Its true definition can therefore only be a genetic one. ${ }^{39}$ Since language is a living organism, always in the process of becoming, the task of the lexicographer is essentially diachronic: to document the evolution of meanings and lexical forms throughout the history of the language.

This Coleridgean view of words as "LIVING POwERs" runs as a leitmotif through Trench's writing on language, particularly his book $O n$

36. Coleridge, Aids to Reflection (London, 1913), p. xix.

37. Ibid., p. xvii. The expressions "living words" and $\check{\varepsilon} \pi \varepsilon \alpha \zeta \omega$ ' books, 3:4237, On the Constitution of Church and State (n. 9 above), p. 166, and Marginalia, ed. George Whalley (Princeton, N.J., 1980), 1:606.

38. Aids to Reflection, p. xvii. See Margaret Wiley, "Coleridge and the Wheels of Intellect," PMLA 67 (1952): 101-12.

39. Wilhelm von Humboldt, On Language: The Diversity of Human Language-Structure and Its Influence on the Mental Development of Mankind, trans. Peter Heath, with an introduction by Hans Aarsleff (Cambridge, 1988), p. 49. I have slightly altered the English translation upon consulting the original German. Coleridge describes his 1806 encounter with Humboldt in The Friend, ed. Barbara E. Rooke, 2 vols. (Princeton, N.J., 1969), 1:510. 
the Study of Words (1851). This enormously popular work, which went through fourteen editions by 1872 , consists mainly of examples of the knowledge and instruction contained in the history of individual words. Trench credits Coleridge with calling his attention to the educational value of the study of words: "A great writer not very long departed from us has here borne witness at once to the pleasantness and profit of this study. 'In a language,' he says, 'like ours, where so many words are derived from other languages, there are few modes of instruction more useful or more amusing than that of accustoming young people to seek for the etymology or primary meaning of the words they use. There are cases in which more knowledge of more value may be conveyed by the history of a word than by the history of a campaign." 40 Trench's reliance on Coleridge's inspiration is apparent in his discussion of the process of desynonymization: "It is to Coleridge that we owe the word 'to desynonymize' ... and his own contributions direct and indirect in this province are both more in number and more important than those of any other English writer; as for instance the disentanglement of 'fanaticism' and 'enthusiasm,' of 'keenness' and 'subtlety,' of 'poetry' and 'poesy;' and that on which he himself laid so great a stress, of 'reason' and "understanding.," 41 Trench also relies on Coleridge in his discussion of specific etymologies, particularly in his analysis of the word 'education', which, he reminds his readers, involves a process of "drawing out" (Latin educere) what is already present in the mind of the student, rather than merely pouring knowledge into an empty vessel. ${ }^{42}$ This view of education as "educing" is a favorite topic of Coleridge, who recurs to it at least half a dozen times in his lectures and published works. ${ }^{43}$ Like Coleridge, Trench reveals a moralizing tendency in his etymological analyses, a tendency that, for better or worse, would later prove congenial to the compilers of the $O E D$, despite their avowed scientific objectives.

40. Trench, On the Study of Words, p. 11, citing Coleridge, Aids to Reflection, p. 5.

41. Trench, "On the Distinction of Words," in On the Study of Words, p. 98n. For these examples of desynonymization. Trench cites Coleridge's Biographia Literaria, The Literany Remains of Samuel Taylor Coleridge, ed. H. N. Coleridge, 4 vols. (London, 1836-39), and Table Talk, ed. H. N. Coleridge, 2 vols. (London, 1835).

42. Trench, "On the Distinction of Words," p. 111.

43. On education as educing, see Coleridge's Miscellaneous Criticism (London, 1936). p. 194, Coleridge's Shakespearean Criticism (Cambridge, Mass., 1930), p. 290, Essays on His Times, ed. David V. Erdman, 3 vols. (Princeton, N.J., 1978), 2:395, The Friend, 1:540n., Lay Sermons, ed. R. J. White (Princeton, N.J., 1972), p. 40, Logic (n. 18 above), p. 9, and On the Constitution of Church and State, p. 48. This etymology is also discussed by Hare and Hare (n. 27 above), p. 188. 
Trench was one of the early members of the Philological Society of London, and he was intimately involved with its project for a new English dictionary. In 1857 he published an eighty-page pamphlet entitled On Some Deficiencies in Our English Dictionaries, which served as a manifesto and rationale for the scholars engaged in compiling the materials for the new dictionary. This pamphlet surveys the existing dictionaries of the English language, focusing especially on Johnson's dictionary as revised and expanded by later editors, criticizing them all for their incompleteness, inaccuracy, and lack of attention to questions of historical development. Trench supports his argument with a wealth of examples drawn from his reading of early English texts. The remedy to these shortcomings, in Trench's view, is not merely to publish a supplement to Johnson's dictionary, as the Philological Society had initially intended, but to create an entirely new dictionary from fresh materials. This pamphlet is the first definitive statement of objectives for the $O E D .^{44}$

As an editor for the new dictionary, the Philological Society chose a man who was thoroughly grounded in the new Germanic philology, highly talented in the field of lexicography, widely read in all periods of English literature, and young enough to see the project through to completion. This man was Herbert Coleridge, the grandson of Samuel Taylor Coleridge, and only twenty-seven years old when he first became associated with the dictionary project in 1857 . He was the son of Sara Coleridge and Henry Nelson Coleridge, who spent most of their adult lives editing Coleridge's posthumous works, and thus he grew up in a home that was virtually a shrine to the memory of his grandfather. Herbert Coleridge was deeply instilled with a knowledge of his grandfather's accomplishments and determined to carry on his legacy in the field of historical linguistics. After receiving a classical education at Eton and Oxford, he went on to practice law in London while pursuing his philological studies during his leisure hours, contributing a series of brilliant papers to the Philological Society and becoming a member in 1857.45 The first fruits of his work on the dictionary are contained in a Glossarial Index to the Printed English Literature of the Thirteenth Century (1859), which was to serve as a guide for readers in that early period, for which existing lexicons

44. For Trench's role in the genesis of the OED, see Aarsleff, The Study of Language in England (n. 3 above), pp. 231-47, 256-63.

45. Biographical information on Herbert Coleridge is derived from Dictionary of National Biography, 1st ed, his role as editor of the OFD is described by William A. Craigie and Charles $\mathrm{T}$. Onions in the historical introduction to the $O E D$ suppl. (1933), pp. vii-x. 
were especially inadequate. By 1860 the dictionary was well underway, as Herbert Coleridge corresponded with scholars throughout Britain and North America, constructed a set of fifty-four wooden pigeonholes to receive their quotation slips, and published a list of formal guidelines, entitled Canones Lexicographici, in collaboration with Trench, Furnivall, and others. ${ }^{46}$ Herbert Coleridge promised to be a competent and highly resourceful editor of the dictionary that his grandfather had first conceived almost half a century before.

Tragically, however, Herbert Coleridge died of consumption in April 1861, at the age of thirty-one, leaving the dictionary project in disarray and resulting in a delay of almost two decades before a suitable replacement could be found. In the meantime, the editorial process ground to a halt, slips were misplaced, readers lost interest, and the entire project came to be regarded as a hopeless enterprise by all but the most ardent of its supporters. In 1878, however, a brash, self-educated schoolteacher from the Scottish border country resumed the task of editing the dictionary. The new editor, James Murray, proved to be not only a brilliant lexicographer but a shrewd publicist as well, and under his leadership the project flourished, attracting hundreds of volunteer readers in England and America. ${ }^{47}$

Murray considered himself a scientist, not a literary scholar, and he paid frequent homage to the high Victorian ideals of science and progress, proudly affirming that "in the Oxford Dictionary, permeated as it is through and through with the scientific method of the century, Lexicography has for the present reached its supreme development." 48 Yet lurking within this scientific method are traces of a Romantic ideology of language that Murray's empiricist rhetoric only partially obscures. In his preface to volume 1 of the $O E D$, for

46. The Canones Lexicographici were written by Herbert Coleridge in 1859 and subsequently revised by other members of the Philological Society. They were published as one of several addenda to vol. 10 (1857) of the Transactions of the Philological Society (actually issued December 1860), along with Trench's essay "On Some Deficiencies in Our English Dictionaries" (n. 3 above), Herbert Coleridge's "Letter to the Very Rev. The Dean of Westminster" (n. 3 above), and the Philological Society's "Proposal for the Publication of a New English Dictionary." The fifty-four wooden pigeonholes constructed by Herbert Coleridge are preserved by the Oxford University Press (see K. M. E. Murray [n. 2 above], p. 136).

47. Realizing the inadequacy of the materials gathered by Furnivall and Herbert Coleridge, James Murray issued "An Appeal to the English-Speaking and EnglishReading Public to Read Books and Make Extracts for the Philological Society's New English Dictionary" (1879), reprinted in Dictionaries: Journal of the Dictionary Society of North America 8 (1986): 216-31 (ed. Richard Bailey).

48. James Murray, The Evolution of English Lexicography (n. 4 above), p. xxiii; see also K. M. F. Murray, pp. 292-93. 
example, Murray remarks that "the creative period of language, the epoch of 'roots,' has never come to an end. The 'origin of language' is not to be sought merely in a far-off Indo-European antiquity, or in a still earlier pre-Aryan yore-time; it is still in perennial process around us." 49 This bold assertion that our language still contains living "roots" is clearly Romantic in tone, perhaps echoing Humboldt's description of language as energeia.

The typographic design of the $O E D$ encodes both its scientific objectives and its underlying Romantic ideology. Murray's most important lexicographic innovations-his provision of dates and precise references for each quotation and his use of multiple typefaces to mark the structure of each lexical entry-reflect his commitment to the scientific ideals of precision and clarity. But these innovations also serve to promote a Romantic view of linguistic evolution by highlighting the narrative dimension of each entry, since each word is "made to tell its own story," and the chaotic profusion of quotations is yoked firmly to an organic paradigm of birth, growth, development, and (perhaps) eventual decay and death. ${ }^{50}$ Thus, for example, the $O E D$ traces 'bless' to a conjectural origin in primitive Teutonic blood sacrifices, drawing an instructive (but etymologically irrelevant) parallel with the Passover ritual in Exod. 12:23. The entry next describes the early historical usage of 'bless' with reference to Christian ceremonies, its gradual association (in "popular etymological consciousness") with the word 'bliss', and its eventual degeneration into humorous, euphemistic, and ironical usages. In this way, an edifying narrative is constructed from the cold, hard facts of linguistic history. Throughout the $O E D$, the narrative structure that Murray imposes upon each lexical entry conforms to an implicit organic paradigm, while his moralizing tendency exemplifies the view of Coleridge (and Trench) that "more knowledge of more value may be conveyed by the history of a word than by the history of a campaign." 51

Coleridge's pervasive influence in the origin of the $O E D$ is also apparent in the activities of its American collaborators. The first American

49. Preface to vol. 1 (1888), $O E D$, p. vii.

50. This organic paradigm is made explicit by Herbert Coleridge, "Letter to the Very Rev. The Dean of Westminster" (n. 3 above).

51. Coleridge, Aids to Reflection (n. 36 above), p. 5. Murray's treatment of the word 'bless' is especially reminiscent of Trench, lecture 3, "On the Morality in Words," in On the Study of Words (n. 35 above), pp. 25-44. Later volumes of the OED, edited by Henry Bradley, William A. Craigie, and Charles T. Onions, show more detailed treatment of vocabulary and less tendency to moralize or to cram quotations into a Procrustean bed of linguistic organicism. On the methods of these later editors, see Richard Bailey, Early Modern English: Additions and Antedatings to the Record of English Vocabulary, 1475-1700 (Hildesheim, 1978), pp. vii-viii. 
editor of the OED was George Perkins Marsh, a cousin and close friend of James Marsh, the American editor of Coleridge's Aids to Reflection (1829) and The Friend (Burlington, Vt., 1831). ${ }^{52}$ James Marsh's eloquent prefaces to these works were widely influential in Transcendentalist circles, perhaps because they stressed the linguistic dimension of Coleridge's philosophy, aptly paraphrased in Emerson's remark that "language is fossil poetry." George Perkins Marsh was something of a Transcendentalist himself, as well as an admirer of Coleridge, and in his years of collaboration with the dictionary project (during the early 1860s) he made certain that Coleridge's published works received careful scrutiny from North American readers. ${ }^{54}$ He describes Coleridge's importance for the dictionary project in his Lectures on the English Language (1859), a popular work that went through several editions in New York and London:

In point of thorough knowledge of the meaning, and constant and scrupulous precision in the use, of individual words, I suppose Coleridge surpasses all other English writers, of whatever period. His works are of great philological value, because they compel the reader to a minute study of his nomenclature, and a nice discrimination between words which he employs in allied, but still distinct senses, and they contribute more powerfully than the works of any other English author to habituate the student to that close observation of the meaning of words which is essential to precision of thought and accuracy of speech. Few writers so often refer to the etymology of words, as a means of ascertaining, defining, or illustrating their meaning, while, at the same time, mere etymology was not sufficiently a passion with Coleridge to be likely to mislead him. ${ }^{5.5}$

Like Trench, Marsh sees Coleridge as a man of extraordinary linguistic self-consciousness, possessing an intuitive grasp of etymology

52. The close intellectual relationship between James and George Perkins Marsh is described by David Loewenthal, Ceorge Perkins Marsh: Versatile Vermonter (New York. 1958), pp. 38-39.

53. Ralph Waldo Emerson, The Poet (1844). Trench cites Emerson's remark about "fossil poetry" in On the Study of Words, p. 11, but he qualifies Emerson's view as "too) narrow," since language may also be regarded as "fossil ethics, or fossil history."

54. George Perkins Marsh was chosen as American secretary for the OEI) in 1859 by Herbert Coleridge, and as Loewenthal points out, "It was his job to promote the dictionary and to guide American scholars, who were to work on American and eighteenth-century English literature" (p. 199). At some later date Marsh was assigned as subeditor for the letter $h$, probably by Fumivall; but he eventually withdrew from the dictionary project due to failing eyesight and lack of encouragement from England. See K. M. E. Murray, p. 176.

55. George Perkins Marsh, Lectures on the Engtish Language (1859), 1st ser., 4th ed. (New York, 1863), pp, 115-16. 
that enables him to discriminate carefully between synonyms and, when necessary, to invent new words. For Marsh, the "philological value" of Coleridge's works is their ability to exemplify precise English usage across an enormous range of difficult and unusual words, and thus (by implication) to provide abundant raw material in the form of citation slips for the projected dictionary.

Marsh's high estimation of Coleridge's significance for the history of the English language is borne out by his ubiquitous presence in the $O E D$ as it was finally published in 1884-1928. The availability of this original version on a computer database makes it relatively easy to survey those words for which Coleridge is represented by a citation. There are 3,569 such entries, many more than we find for such major canonical writers as Wordsworth $(1,895)$, George Eliot $(2,601)$, Burns $(2,703)$, Emerson (2,871), or Browning (2,959), although not in the same league with Tennyson $(6,831)$, Dickens $(7,495)$, Chaucer $(11,690)$, Milton $(12,292)$, Sir Walter Scott $(16,191)$, or Shakespeare $(32,857)$. What makes Coleridge's contribution to the $O E D$ citation index so remarkable is not the sheer bulk of his entries but the astonishing number of times that he seems to be coining a new word or reviving an old and disused sense of a word. Coleridge provides the first recorded usage for over six hundred words in the OED. Of course, it is not certain that he actually invented all of these words, since words tend to exist in spoken discourse before they are written down and since the $O E D$ may fail to record their first appearance in print; but the $O E D$ still testifies to Coleridge's incredible talent for linguistic innovation. ${ }^{56}$ In several cases, Coleridge himself declares that he is inventing a new word, as for example 'aloofness', 'aspheterize', 'athanasiophagous', 'clerisy', 'esemplastic', 'intensify', 'potenziate', 'psilanthropist', 'reliability', 'statuesque', 'Theo-mammonists', and 'vaccimulgence'. In other cases, Coleridge claims to be reviving an old and forgotten word, such as 'agglomerative', 'haemony', 'multeity', and 'sensuous'. Some of his word coinages are truly imaginative, others merely bizarre; while some have passed so effortlessly into common usage that we are surprised to

56. The deficiencies of the documentation in the OED, especially in Middle English and the early modern period, are now apparent. The Middle English Dictionary provides much more comprehensive documentation; sec also Bailey (n. 51 above); and Jürgen Schäfer, Early Modern English Lexicography, 2 vols. (Oxford, 1989). Schäfer has documented over six thousand revisions to the $O E D$, and he claims that there are 100,000 antedatings still to be discovered in the early modern period (2:4). For some implications of Bailey's and Schäfer's findings, see Thomas W. Russell, "Shakespearcan Coinages: Fewer Than Supposed?" English Language Notes 26 (March 1989): 8-18. It is possible that the number of Coleridgean coinages will decrease as a result of future lexicographic research, but the ongoing publication of Coleridge's Notebooks and Marginalia continues to reveal many new coinages. 
find that they are so recently minted. In the bizarre category, we find dozens of words like 'anatopism' (a faulty arrangement), 'exforcipate' (to extract with forceps), 'finific' (putting a limit to something), 'heautophany' (self-manifestation), 'linguipotence' (mastery of languages), 'misology' (hatred of reason), 'nasoductility' (capacity of being led by the nose), 'obitaneously' (by the way), 'parthenolatry' (virgin-worship), 'pinguinitescent' (having a greasy lustre), 'pleistodox' (holding the opinion of the majority), and 'somniloquent' (talking in sleep). In the truly imaginative category belong such words as 'neuro-pathology', 'subconsciousness', 'psycho-analytical', and 'psychosomatic', which anticipate Freudian terminology by almost a century, and the astonishing word 'relativity', which looks forward to another key twentieth-century concept. Perhaps even more surprising is the discovery that a large number of familiar, everyday words were invented (or first recorded) by Coleridge; a short list would include: actualize, adaptive, appraisal, artifact, associative, atomistic, bathetic, belletristic, bipolar, bisexual, chromatology, cosmological, cyclical, egoistic, factual, fatalistic, fore-grounded, greenery, heuristic, historicism, housemate, interdependence, marginalia, negativity, otherworldliness. phenomenal, productivity, protozoa, realism, resurgence, romanticise, sectarianism, Shakspeareanize, soulmate, Spenserian, statuesque, subjectivity, technique, totalize, uniqueness, and many more. ${ }^{57}$ These everyday words, even more than his exotic coinages, reveal Coleridge as one of the most prolific creators of new words in the nineteenth century, and they suggest his vital role in the formation of contemporary English usage, especially in the discourses of criticism, philosophy, and science.

Coleridge was the main prototype for a dominant cultural figure known as the Victorian Sage, described by John Holloway as dispensing "a knowledge that is somehow both elusive and simple ... and that ultimately is known by a special sense, an intuition. ${ }^{58}$ This intuitive process relies heavily on a set of epistemological premises that Coleridge, more than any of his contemporaries, articulated for the English reading public; his Romantic ideology, merging philosophical idealism with linguistic organicism, was promulgated throughout Britain and North America in such works as The Friend, Biographia Lit-

57. Textual references for these words may be found in the Appendix, "Coleridgean Coinages: A Reference List" (pp. 24-45). For further discussion of Coleridge's linguistic innovations, see Owen Barfield, "Coleridge's Enjoyment of Words," in Coleridge's Variety, ed. John Beer (Pittsburgh, 1974), pp. 204-18.

58. John Holloway, The Victorian Sage: Studies in Argument (London, 1953), p. 8. Aarsleff, From Locke to Saussure (n. 1 above), pp. 37-38, examines the linguistic philosophy of the Victorian Sage. 
eraria, and Aids to Reflection. Through his public lectures, which encouraged the historical study of early English authors, Coleridge also contributed to popular support for the new Germanic philology and for the new English dictionary that would embody its historical principles. Following in Coleridge's footsteps, Thomas Carlyle cultivated an extensive knowledge of German literature and philosophy, first establishing his credentials as a Victorian Sage in Sartor Resartus, which (despite its overtly satirical tone) adopts an essentially Coleridgean perspective in philosophy and linguistics. ${ }^{59}$ Like Coleridge, Carlyle frequently invokes etymology as a means of persuasion, although his awareness of the new philology was surprisingly limited. ${ }^{60}$ Alfred Tennyson, who attended Trinity College at the height of Coleridge's reputation there, was deeply committed to a Coleridgean aesthetic, especially in his early development as a lyric poet. $^{61}$ Through his Cambridge education, Tennyson also acquired a close familiarity with the new philology, often alluding to abstruse Germanic etymologies and revealing a precise knowledge of Old English works recently published by the Early English Text Society. ${ }^{62}$ In compiling the $O E D$, James Murray not only drew extensively from the published works of the Victorian Sages but entered into personal correspondence with Tennyson, George Meredith, Thomas Hardy, Thomas Huxley, and a host of other literary and scientific luminaries, thus imbuing the $O E D$ with their precise lexical knowledge and their immense cultural authority. As the "intellectual parent" of these Victorian Sages, Coleridge played a formative role in their conception of language, especially in their sense of its organic development and their close attention to the history of individual words; and these widely disseminated ideas and values greatly facilitated the

59. On Carlyle's response to Coleridge, see Charles R. Sanders, Carlyle's Friendships and Other Studies (Durham, N.C., 1977), pp. 36-60, and Coleridge and the Broad Church Movement (n. 21 above), pp. 163-76.

60. Carlyle shows very little knowledge of the new Germanic philology, deriving his etymologies instead from Horne Tooke, Samuel Johnson, and his own fertile and inventive brain. On this topic, see G. B. Tennyson, Sartor Called Resartus: The Genesis, Structure, and Style of Thomas Carlyle's First Major Work (Princeton, N.J., 1965), pp. 26266; and Brian Rosenberg, "Etymology as Propaganda: A Note on Carlyle's Use of Word-Origins," English Language Notes 24 (March 1987): 29-34.

61. On Tennyson's Coleridgean conception of poetry, see Lawrence Poston, "Poetry as Pure Act: A Coleridgean Ideal in Early Victorian England," Modern Philology 84 (1986): 162-84. On Tennyson's response to Coleridge's linguistic philosophy, see Donald S. Hair, "Matter-molded Forms of Speech," Victorian Poetry 27 (1989): 7-15.

62. Tennyson's knowledge and poetic use of the new Germanic philology is discussed by Patrick Greig Scott, "Flowering in a Lonely Word': Tennyson and the Victorian Study of Language," Victorian Poetry 18 (1980): 371-81. 
compilation of the $O E D$, vaster and more comprehensive than any previous dictionary. ${ }^{63}$

In the final analysis, then, Coleridge's influence on the content and lexicographic methods of the OED seems less substantial than his role in creating the ideological climate that provided the OED with the rationale and cultural authority so essential to its production. Coleridge's inspiring remarks on the importance of etymology, his articulation of an organic paradigm of linguistic evolution, and his advocacy of the new Germanic philology contributed to a unique cultural situation in which hundreds of amateur philologists possessed the skills and motivation required for the compilation of this vast historical dictionary. Despite its close association with major institutions of the British academic and political establishment, we should not assume that the $O E D$ fulfilled an essentially conservative social function. The $O E D$ served as a means of empowerment for hundreds of scholars, many working outside the universities and far from the centers of power, and many belonging to marginal social groups. Dissenters, women, ethnic minorities, even certified lunatics participated in the making of the $O E D)^{64}$ A large and enthusiastic contingent of Americans also participated, marking the first large-scale scholarly collaboration between the two continents and lending social legitimacy to fledgling academic programs in English language and literature on both sides of the Atlantic. The $O E D$ thus played a catalytic role in the formation of a new professional intellectual class, the "clerisy," and in fostering the creation of new academic institutions for the pursuit of philological studies. ${ }^{65}$ The peaceful coexistence of scientific objectives and Romantic ideologies within the $O E D$ project-and within the mind of James Murray himself--suggests the fundamentally pluralistic, inclusive nature of the enterprise.

63. Holloway, p. 13, describes Coleridge as "an intellectual parent of all these writers." For a survey of Coleridge's influence, see Graham Hough, "Coleridge and the Victorians," in The Linglish Mind: Studies in the English Moralists Presented to Basil Willey. ed. H. S. Davis and George Watson (Cambridge, 1964), pp. 175-92. On James Murray's correspondence with Tennyson and other contemporary writers, see K. M. F. Murray (n. 2 above), pp. 190, 201, and 367, n. 48.

64. James Murray was a staunch liberal in politics, often surprisingly hostile (o) the British establishment, and he shared with Fumivall a commitment to the inclusion of "outsiders" in the OHI) project (see n. 8 above). On their political views, see K. M. E. Murray, pp. 88, 122, 290-91, 334-35.

65. For early development of academic programs in English, see Phyllis Franklin, "English Studies: The World of Scholarship in 1883," PMLA 99 (1984): 356-69. Franklin documents the crucial role of George Perkins Marsh (first American secretary for the $O E D$ ) in the establishment of English studies in the Lnited States. 
The Oxford English Dictionary remains one of the most enduring intellectual legacies of the Victorian era, a work still widely consulted and still invested by many of its readers with a quasi-scriptural authority. To this day, the $O E D$ enjoys a popular reputation for total completeness and accuracy, no doubt a lingering result of the prestige it acquired during its first publication. Victorian readers of the OED typically admired its scientific rigor but felt overwhelmed by its encyclopedic inclusiveness; an early reviewer observed that "everything is to be found there, but one feels that human faculties are inadequate to penetrate the details of so vast a collection." 66 Today, however, the original $O E D$ can seem lexically and culturally circumscribed, quaint, and even outmoded (especially by comparison with the new $O E D$ ), and from our present historical perspective its Romantic ideology of linguistic organicism is detectable in the implicit narrative structure of its lexical entries. More than just a comprehensive reference work, the $O E D$ may now be regarded as the product of its own historical imperative. Yet the routine scholarly utility of the $O E D$ is not in question here, aside from a caveat lector with regard to its alleged descriptive neutrality. Indeed, there is cause for renewed appreciation, not just for the epic scope of the accomplishment embodied in its publication but for the imaginative leap involved in conceiving its possibility. That initial leap was taken by Coleridge; the $O E D$ represents the culmination of a plan that he first sketched out in the Biographia Literaria, and it fulfills his dream of a "philosophical Romance to explain the whole growth of Language. $" 67$

\section{A P P E N D I X}

\section{COLERIDGEAN COINAGES: A REFERENGE LIST}

This list includes all known lexical items for which Coleridge provides the first recorded citation, regardless of whether the word (or phrase) is now current, rare, obsolete, or used in English in a different sense. It does not include already existent words that Coleridge employed in a new sense, or words that he revived from older writers (both large and interesting categories). Compilation was made by a computerized

66. Henry Reeve, "The Literature and Language of the Age," Edinburgh Review 169 (1889): 350, cited by Dowling (n. 1 above), p. 99. See also Leslie Bivens, "NineteenthCentury Reactions to the OED: An Annotated Bibliography," Dictionaries: Journal of the Dictionary Society of North America 3 (1980-81): 146-52.

67. Biographia Literaria (n. 12 above), 1:239n, Notebooks (n. 14 above), 1:1646. 
search of the original $O E D$ on CD-ROM, and each reference was crosschecked against the $O E D$, second edition (1989). In addition, this list incorporates several lexical items noted by Roland Hall, Joshua Neumann, and Fred Shapiro; these items are followed by the author's name in parentheses (see the section of abbreviations below). I have also consulted the indexes to the Collected Coleridge volumes $(C C)$ and the Notebooks under the entry for $O E D$. My own lexical discoveries are marked "McKusick." This list collects the best information presently available, but it will surely grow as the remaining Coleridge manuscripts and marginalia are published and indexed.

Wherever possible, citations have been located in modern standard editions; these are indicated by the abbreviations $C C$, Notebooks, Letters, or $P W$. Otherwise, textual references are given in the form cited by $O E D$. Works otherwise unattributed are by Samuel Taylor Coleridge.

The phrase "not in $O E D$ " indicates that this lexical form does not appear in the $O E D$, second edition (1989).

The phrase "antedates $O E D$ " indicates that this citation antedates the earliest citation in $O E D$ for this particular lexical form. The earliest date cited in $O E D$ is given in brackets, followed by "STC" if Coleridge is the source of that citation.

\section{Abbreviations ${ }^{68}$}

$A R$

Biographia $(C G)$

$\operatorname{ces}(C C)$

Confess Enq Spirit

$\operatorname{EOT}(C C)$

Friend $(C C)$

Hall

Inquiring Spint

Lay Serm $(C C)$
Aids to Reflection (London, 1825, 1839, 1848, 1854, 1861, 1865,1913 )

Biographia Literaria, ed. James Engell and W. Jackson Bate, 2 vols. (Princeton, N.J., 1983)

On the Constitution of Church and State, ed. John Colmer (Princeton, N.J., 1976)

Confessions of an Enquiring Spirit, ed. H. N. Coleridgc (London, 1840)

Essays on His Times, ed. David V. Erdman, 3 vols. (Princeton, N.J., 1978)

The Friend, ed. Barbara E. Rooke, 2 vols. (Princeton, N.J., 1969)

Roland Hall, "Words from Coleridge's Biographia Literaria," Notes and Queries 17 (1970): 171-74

Inquiring Spirit: A New Presentation of Coleridge from His Published and Unpublished Prose Writings, ed. Kathleen Coburn (London, 1951)

Iay Sermons, ed. R. J. White (Princeton, N.J., 1972)

68. For fuller versions of the abbreviations that appear in the word list but are not included in the following listing, see the bibliography in the OFD). 
Lects on Lit (CC) Lectures 1808-1819: On Literature, ed. R. A. Foakes, 2 vols. (Princeton, N.J., 1987)

Letters (1956) Collected Letters of Samuel Taylor Coleridge, ed. E. L. Griggs, 6 vols. (Oxford, 1956-71)

Life of Wesley $\quad$ Robert Southey, The Life of Wesley; and the Rise and Progress of Methodism, with notes by S. T. Coleridge, 3d ed., 2 vols. (London, 1846)

Lit Rem

The Literary Remains of Samuel Taylor Coleridge, ed. H. N. Coleridge, 4 vols. (London, 1836-39)

McKusick

Marginalia

James C. McKusick (indicates new lexical discoveries)

Marginalia, ed. George Whalley, 2 pts. to date (Princeton, N.J., 1980-)

Neumann

Joshua Neumann, "Coleridge on the English Language," PMLA 63 (1948): 642-61

Notebooks

The Notebooks of Samuel Taylor Coleridge, ed. Kathleen Coburn, 4 vols. to date (Princeton, N.J., 1957-)

Phil Lects

The Philosophical Lectures, 1818-1819, Hitherto Unpublished, ed. Kathleen Coburn (New York, 1949)

Princ Genial Crit

On the Principles of Genial Criticism (1814), in Biographia Literaria, ed. J. Shawcross (Oxford, 1907), 2:219-43

$P W(1912)$

The Complete Poetical Works of Samuel Taylor Coleridge, ed. Ernest H. Coleridge, 2 vols. (Oxford, 1912)

Shapiro

Fred Shapiro, "Neologisms in Coleridge's Notebooks," Notes and Queries 32 (1985): 346-47

STC

Samuel Taylor Coleridge

Theory of Life Hints towards the Formation of a More Comprehensive Theory of Life, ed. Seth B. Watson (London, 1848)

$T T(C C)$

Table Talk, ed. Carl Woodring, 2 vols. (Princeton, N.J., 1990)

Word List ${ }^{69}$

$\begin{array}{lll}\text { absolute subject } & 1817 & \text { Biographia }(C C) 1: 278 \\ \text { absundering } & 1825 & \text { Notebooks } 4: 5217 \text {; not in } \text { OED } \\ \text { acclimatement } & 1823 & \text { Notes Theological (1853) } 401 \\ \text { actualization } & 1825 & \text { AR }(1848) 1: 221 \\ \text { actualize } & 1809 & \text { Friend }(C C) 2: 73 \text { (Neumann) } \\ \text { actualized } & 1816 & \text { Lay Serm }(C C) 23 \text {; antedates } \text { OED }[1825 \\ & & \text { STC }] \text { (McKusick) } \\ \text { actualizing } & 1825 & \text { AR }(1848) 1: 28 \\ \text { actuity } & 1819 & \text { Notebooks } 4: 4551 \text {; not in OED } \\ \text { adaptive } & 1825 & \text { AR }(1825) 193\end{array}$

69. In the column of dates, "a" (as in "a1834") stands for ante or before; "c" stands for circa. 


\begin{tabular}{|c|c|c|}
\hline adducer & 1809 & Friend (CC) 2:110 \\
\hline adducible & 1799 & $\operatorname{EOT}(C C) 1: 51$ \\
\hline admarginate & a 1834 & In Noah Webster, Am Dict (1864) \\
\hline adynamic & 1825 & Notebooks 4:5189; antedates OED [1829] \\
\hline affectible & a 1834 & Notes Theological (1853) 4 \\
\hline after-effect & 1817 & Biographia (CC) $2: 143$ \\
\hline agglomerative & 1817 & Poems, etc 139 [OED; untraced, JMK] \\
\hline aglow & 1817 & Biographia (CC) 1:238 \\
\hline agriculturer & 1812 & $\operatorname{EOT}(C C) 2: 129$ \\
\hline all in each & 1817 & Biographia (CC) 2:82; not in $O E D$ (Hall) \\
\hline alliterativeness & 1818 & Iit Rem 1:92 \\
\hline allocosmite & 1830 & CES (CC) 165; not in OHD (McKusick) \\
\hline allogeneity & 1825 & Lit Rem $2: 336$ \\
\hline allophoby & 1819 & Notebooks $4: 4534$; not in $O H D$ \\
\hline alogology & $1820-21$ & Notebooks $4: 4767 ;$ not in $O F D$ \\
\hline amphoteric & 1823 & Notebooks 4:4942; antedates $O E D$ [1849] \\
\hline amphoterism & 1820 & Notebooks 4:4662; not in OHD \\
\hline amputator & 1809 & Friend $(C C) 2: 45$ \\
\hline anaclete & 1817 & $\operatorname{EOT}(C C) 2: 473$ \\
\hline analogon & 1804 & $\begin{array}{l}\text { Letters (1956) 2:1079; antedates OHI) } \\
\text { [1810 STC] (McKusick) }\end{array}$ \\
\hline anarchise & 1800 & $E O T(C O) 1: 115$ \\
\hline anatopism & 1812 & Lit Rem 1:317 (Neumann) \\
\hline annullable & 1799 & $\operatorname{EOT}(C C) 1: 56$ \\
\hline anthropic & 1819 & Notebooks 4:4534; antedates OED [ 1859] \\
\hline anthropognosy & 1825 & Notebooks $4: 5232 ; \mathrm{not}$ in $O E D$ \\
\hline anthropogony & 1825 & Notebooks 4:5254; antedates OED [a1871] \\
\hline anthropotomy & 1825 & Notebooks 4:5207; antedates OED $[1855]$ \\
\hline anti-logical & $\mathrm{c} 1814$ & Notes Theological (1853) 142 \\
\hline antimnemonic & 1817 & Biographia (CC) $1: 49$ \\
\hline anti-odontalgic: & 1817 & EOT (CC) $2: 468$ \\
\hline antipathist & 1817 & "Ne Plus Lltra" line 2 in $P W(1912) 1: 431$ \\
\hline anti-philosophic & 1818 & Phil Lerts (1949) 72 \\
\hline antipolemist & 1817 & Biographia $(C C) 1: 179$ \\
\hline anti-scholastic & a 1834 & Notes Theological (1853) 264 \\
\hline apocalypt & 1834 & Lit Rem 3:168 \\
\hline appertiency & 1822 & Nolebooks $4: 4887 ;$ not in $O E D$ \\
\hline appraisal & 1817 & Biographia (CC) 2:19 (Neumann) \\
\hline aquiform & 1818 & $\begin{array}{l}\text { Notebooks } 3: 4418 ; \text { antedates } O E D[1835] \\
\quad \text { (Shapiro) }\end{array}$ \\
\hline arborescence & 1823 & Notebooks 4:4984; antedates $O E D[1856]$ \\
\hline archology & 1825 & Lit Rem $2: 339$ \\
\hline argumentum in circulo & 1817 & Biographia (CC) 2:244; not in OED (Hall) \\
\hline artefact & 1821 & $\begin{array}{l}\text { Biackw Mag 10 (1821): 256; Lit Rem } 3: 347 \\
\text { (Neumann) }\end{array}$ \\
\hline askingly & 1797 & "To a Young Ass" linc 23 in $P W(1912) 1: 75$ \\
\hline
\end{tabular}




\begin{tabular}{|c|c|c|}
\hline aspheterize & 1794 & Letters (1956) 1:84 (Neumann) \\
\hline associative & 1812 & Lit Rem 1:326 (Neumann) \\
\hline astoundment & 1818 & Friend $(C C) 1: 519$ \\
\hline asympatheia & 1818 & Lects on Lit (CG) 2:174; not in $O E D$ \\
\hline athanasiophagous & 1800 & $\begin{array}{l}\text { Letters (1956) } 1: 557 ; \text { not in } O E D \\
\quad(\text { Neumann) }\end{array}$ \\
\hline atomistic & 1818 & Friend $(C C) 1: 94 n$ \\
\hline attainability & 1818 & Friend $(C C) 1: 439$ \\
\hline aureity & 1825 & $A R(1848)$, app. C (1878) 1:379 (Neumann) \\
\hline azoic & 1820 & Notebooks 4:4880; antedates $O E D[1854]$ \\
\hline bathetic & 1834 & Lit Rem 2:163 (Neumann) \\
\hline be-belzebubbed & 1814 & Let. I 6 July [untraced, JMK] \\
\hline belletristic & 1821 & Letters (1956) 5:169 (Neumann) \\
\hline besetter & 1819 & Letters (1956) 4:969 \\
\hline bibliolater & 1820 & $\begin{array}{l}\text { Letters (1956) 5:37; antedates OFD [1847] } \\
\quad \text { (McKusick) }\end{array}$ \\
\hline bibliological & 1808 & $\begin{array}{l}\text { Notebooks 3:3277; antedates } O E D \text { [no } \\
\text { citations] (Shapiro) }\end{array}$ \\
\hline bi-polar & 1810 & Friend (CG) $\mathbf{1}: 492$ \\
\hline bisexual & 1825 & $A R(1848) 1: 204$ \\
\hline boastfulness & 1825 & $A R(1865) 168$ \\
\hline bottle-green & 1804 & $\begin{array}{l}\text { Notebooks 2:2026; antedates } O E D[1816] \\
\quad \text { (Shapiro) }\end{array}$ \\
\hline busyness & 1819 & $\begin{array}{l}\text { Lects on Lit (CC) 2:365; antedates OED } \\
\quad[1849]\end{array}$ \\
\hline Carololatreia & $c 1811$ & Marginalia $(C C) 1: 257 ;$ not in $O E D$ \\
\hline catechismal & $1814-24$ & Marginalia $(C C) 2: 657$ \\
\hline categorical imperative & 1817 & $\begin{array}{l}\text { Biographia (CO) 1:154; antedates OED } \\
\text { [1827] (Hall) }\end{array}$ \\
\hline Catholozoa & 1824 & Notebooks $4: 5181$; not in $O E D$ \\
\hline celestialize & 1810 & $\begin{array}{l}\text { Notebooks 3:3729; antedates OED [1826] } \\
\text { (Shapiro) }\end{array}$ \\
\hline centro-peripheric & 1826 & Notebooks $4: 5406 ;$ not in $O E D$ \\
\hline centro-peripherical & 1826 & Notebooks 4:5406; not in OED \\
\hline chirocosmetics & 1819 & Lit Rem 2:119 \\
\hline chit-chatters & 1813 & Lects on Lit (CC) 1:551; not in OED \\
\hline Christo-dúly & $1814-24$ & Marginalia ( $C C$ ) 2:662; not in $O E D$ \\
\hline Christolatry & $1814-24$ & Marginalia (CC) 2:662 \\
\hline Christologist & 1805 & $\begin{array}{l}\text { Notebooks 2:2444; antedates OED [1846] } \\
\quad \text { (Shapiro) }\end{array}$ \\
\hline chromatology & $1809-17$ & $\begin{array}{l}\text { Notebooks } 3: 3606 \text {; antedates } O E D[1846] \\
\quad \text { (Shapiro) }\end{array}$ \\
\hline citizeness & 1796 & Letters $(1956) 1: 176 \mathrm{n}$ \\
\hline classific & 1818 & Friend $(C C) 1: 466$ \\
\hline clerisy & 1818 & Lects on Lit (CC) 2:236 (Neumann) \\
\hline clientism & 1799 & $E O T(C C) 1: 34 ;$ not in $O E D$ \\
\hline
\end{tabular}




\begin{tabular}{|c|c|c|}
\hline cloudage & 1803 & $\begin{array}{l}\text { Notebooks 1:1635; antedates } O E D[1818 \\
\text { STC] (Shapiro) }\end{array}$ \\
\hline cloudland & 1817 & $\begin{array}{l}\text { "Fancy in Nubibus" line } 9 \text { in } P W(1912) \\
1: 435\end{array}$ \\
\hline co-adunative & 1818 & $\begin{array}{l}\text { Friend (CC) 1:456; antedates } O E D \text { [a } 1834 \\
\text { STC] (McKusick) }\end{array}$ \\
\hline co-domestication & 1819 & Lit Rem 2:193 \\
\hline cognateness & 1816 & Lay Serm $(C C) 25$ \\
\hline co-herald & 1802 & $\begin{array}{l}\text { "Hymn before Sunrise" line } 35 \text { in } P W \\
\text { (1912) } 1: 378\end{array}$ \\
\hline coherentific & $1817-18$ & Marginalia $(C C) 1: 780$ \\
\hline coinstantaneity & 1818 & Lects on Lit $(C C)$ 2:221 \\
\hline co-inherence & 1820 & $\begin{array}{l}\text { Notebooks 4:4644; antedates } O E D[1825 \\
\text { STC] }\end{array}$ \\
\hline co-inherent & 1817 & $\begin{array}{l}\text { Biographia (CC) 1:143; } 1820 \text { Notebooks } \\
\quad 4: 4644\end{array}$ \\
\hline co-involution & 1819 & Notebooks 4:4558; not in $O E D$ \\
\hline combatable & 1818 & Lects on Lit $(C C) 2: 326$ \\
\hline commissive & 1816 & Lil Rem 1:389 \\
\hline compositite & $1820-21$ & Notebooks 4:4764; not in $O E D$ \\
\hline conceivability & 1825 & $A R(1825) 97$ \\
\hline conchozetetic & 1819 & Notebooks 4:4608; not in $O E D$ (Neumann) \\
\hline concipiency & 1825 & $A R(1848) 1: 178$ \\
\hline congeneric & a1834 & Lit Rem 3:333 \\
\hline conpercipience & 1820 & Notebooks 4:4717; not in $O E D$ \\
\hline continentalist & 1834 & $T T(C C) 2: 295$ \\
\hline co-organised & 1825 & $A R(1854) 120$ \\
\hline copernicise & 1818 & Friend ( $C C) 1: 486$ \\
\hline co-presence & 1817 & Biographia (CC) 1:255 \\
\hline co-present & 1817 & Biographia (CC) $1: 114$ \\
\hline corporealize & 1797 & Athenaeum (July 19, 1890), p. 98, col. 2 \\
\hline corradial & 1825 & $A R(1848) 1: 291$ \\
\hline corradiate & 1800 & Piccolom 4.1 .10 in $P W(1912) 2: 685$ \\
\hline corrallighine & a1834 & $\begin{array}{l}\text { Fraser's Mag } 12 \text { (1835): 496; not in } O E D \\
\quad \text { (McKusick) }\end{array}$ \\
\hline cosmetor & $1825-26$ & Notebooks 4:5300; not in $O E D$ \\
\hline cosmological & 1825 & $A R(1848) 1: 140$ \\
\hline cosmotheism & 1825 & Lit Rem $2: 326$ \\
\hline cosmozöic & 1819 & Notebooks 4:4564; not in $O E D$ \\
\hline credentialize & $1812-34$ & Marginalia $(C C) 2: 39 ;$ not in $O E D$ \\
\hline credibilize & 1818 & Lects on Lit $(C C) 2: 295$ \\
\hline creedsman & 1810 & Lit Rem 4:352 \\
\hline criterional & 1830 & $T T(C C) 1: 201$ \\
\hline crumenically & 1825 & Letters (1956) 5:418 (Neumann) \\
\hline cyclical & 1817 & Biographia (CC) 1:250, 1:267 \\
\hline dastardling & 1800 & Piccolom 4.3 .52 in $P W(1912) 2: 688$ \\
\hline day-dawn & 1813 & Remorse 4.2 .53 in $P W(1912) 2: 866$ \\
\hline
\end{tabular}




\begin{tabular}{|c|c|c|}
\hline day-thoughts & $1820-34$ & $\begin{array}{l}\text { Life of Wesley (1846) 2:12; not in } O E D \\
\text { (McKusick) }\end{array}$ \\
\hline death-fire & 1796 & $\begin{array}{l}\text { “Ode Departing Year" line } 59 \text { in } P W \\
\text { (1912) } 1: 163\end{array}$ \\
\hline deathify & a1834 & Lit Rem 2:163 \\
\hline deisidaemoniac & 1823 & Notebooks 4:4938; not in OED \\
\hline demonstrability & 1817 & $\begin{array}{l}\text { Biographia }(C C) \text { 1:203; antedates } O E D \\
\quad \text { [1825 STC] (Hall) }\end{array}$ \\
\hline derb & 1825 & $A R(1825) 329$ (Neumann) \\
\hline despoinism & 1819 & Notebooks 4:4512; not in $O E D$ \\
\hline despotize & 1794 & $\begin{array}{l}\text { Fall of Robespierre } 1.125 \text {; antedates } O E D \\
\quad[1799]\end{array}$ \\
\hline desynonymize & 1803 & $\begin{array}{l}\text { Notebooks 1:1336; antedates } O E D[1817 \\
\quad \text { STC] (McKusick) }\end{array}$ \\
\hline detachability & 1825 & $A R(1861) 255$ \\
\hline determinability & 1825 & $A R(1848) 1: 195$ \\
\hline diabolography & a 1834 & $\begin{array}{l}\text { Inquiring Spirit no. } 40 ; \text { not in } O E D \\
\text { (McKusick) }\end{array}$ \\
\hline dimidiety & 1824 & Notebooks $4: 5144 ;$ not in $O E D$ \\
\hline disactualizing & 1825 & Notebooks 4:5249; not in $O E D$ \\
\hline disclosal & 1795 & Conciones ad Populum 37 \\
\hline disfleece & 1811 & $E O T(C C) 2: 304 ;$ not in $O E D$ \\
\hline distinctity & 1825 & Notebooks $4: 5233 ; 1830$ Lit Rem 3:2, 3:123 \\
\hline downheartedness & 1813 & $E O T(C C) 3: 141 ;$ antedates $O E D[$ a 1863$]$ \\
\hline dropless & 1798 & "Picture" line 40 in $P W(1912) 1: 370$ \\
\hline ear-say & 1817 & Biographia $(C C) 1: 52 \mathrm{n}$ \\
\hline ecarceration & 1825 & Notebooks $4: 5217 ;$ not in $O E D$ \\
\hline eddying & 1802 & $\begin{array}{l}\text { "Dejection: An Ode" line } 136 \text { in } P W \\
\text { (1912) 1:368; antedates } O E D \text { [1817 } \\
\text { STC] (McKusick) }\end{array}$ \\
\hline egoistic & a1834 & Lit Rem 4:434 (Neumann) \\
\hline emblazonment & 1799 & $\begin{array}{l}\text { "Ode Duchess Devonshire" line } 12 \text { in PW } \\
\text { (1912) } 1: 336\end{array}$ \\
\hline embreastment & 1799 & Letters (1956) 1:508 \\
\hline enclesia & 1823 & $\begin{array}{l}\text { Notebooks 4:5082; CES } S(C C) 45 ; \text { not in } \\
\quad \text { OED }\end{array}$ \\
\hline entempests & 1800 & $\begin{array}{l}\text { "Tallyrand to Lord Grenville" line } 68 \text { in } \\
\quad P W(1912) 1: 343\end{array}$ \\
\hline entify & 1810 & $\begin{array}{l}\text { Notebooks 3:3934; antedates } O E D[1882] \\
\quad \text { (Shapiro) }\end{array}$ \\
\hline entomozoa & 1824 & Notebooks $4: 5181 ;$ not in $O E D$ \\
\hline epoch-forming & 1816 & $\begin{array}{l}\text { Lay Serm }(C G) 14 ; 1823 \text { Notebooks 4:4941 } \\
\text { (Neumann) }\end{array}$ \\
\hline equi-radial & 1817 & Biographia $(C C) 1: 269$ \\
\hline esemplastic & 1817 & Biographia (CC) 1:168 (Neumann) \\
\hline esurience & 1825 & Lit Rem 2:338 (Neumann) \\
\hline eudamonist & 1818 & Lit Rem $1: 273$ \\
\hline
\end{tabular}




\begin{tabular}{|c|c|c|}
\hline evenomate & c1831 & Marginalia (CC) 2:298 \\
\hline ever active & 1817 & Biographia (CC) 2:22; not in $O E D$ (Hall) \\
\hline excarceration & 1825 & Notebooks $4: 5217 ;$ not in $O E D$ \\
\hline excellion & 1820 & Notebooks $4: 4653 ;$ not in $O E D$ \\
\hline excitancy & 1819 & Notebooks 4:4538; Lit Rem 4:25 \\
\hline exemplifiable & 1808 & Marginalia $(C C) 2: 1126$ \\
\hline exforcipate & al834 & Lit Rem $3: 383$ \\
\hline exhibitable & a1834 & Lit Rem 3:388 \\
\hline existentially & a1834 & In Noah Webster, Am Dict (1864) \\
\hline exoterice & 1817 & Biographia (CC) 1:160; not in OED (Hall) \\
\hline experiential & 1816 & Lay Serm $(C C) 68$ \\
\hline experimentalism & a 1834 & Lit Rem 3:159 \\
\hline experimentative & 1825 & $A R$ preface (1848) $1: 19$ (Neumann) \\
\hline extensity & 1801 & Marginalia (CC) $2: 646$ \\
\hline extroitive & 1815 & $\begin{array}{l}\text { Notebooks 3:4272; antedates } \text { OED }[1834 \\
\text { STC] (Shapiro) }\end{array}$ \\
\hline factual & $1820-34$ & Life of Wesley (1846) 2:11 (Neumann) \\
\hline fatalistic & 1832 & $T T(C C) 1: 270($ Neumann $)$ \\
\hline featureliness & 1818 & Lects on Lit (CC) 2:160 \\
\hline featurely & 1819 & Lects on Lit (CC) $2: 378$ \\
\hline femineity & 1820 & Lets, Convs, ERers (1836) 1:72 \\
\hline Fichtean & 1817 & Biographia (CC) 1:158n (Hall) \\
\hline finific & 1830 & Lit Rem 3:2 (Neumann) \\
\hline fister & 1825 & Lit Rem $4: 281$ \\
\hline fixive & a 1834 & $\begin{array}{l}\text { Marginalia to Steffens in Biographia } \\
\text { (1847) 1:322, app. }\end{array}$ \\
\hline flatter-blind & 1808 & $\begin{array}{l}\text { Lerts on Lit (CO) 1:142; antedates OHI) } \\
\text { [1818 STC] }\end{array}$ \\
\hline flittery & a 1834 & Lit Rem 4:287 \\
\hline flounder-flat & 1819 & Lit Rem 2:119 \\
\hline fluidize & 1818 & $\begin{array}{l}\text { Notebooks 3:4418; antedates } O E I)[1855] \\
\quad \text { (Shapiro) }\end{array}$ \\
\hline fonti-fontal & 1825 & Notebooks 4:5249; not in $O E I$ \\
\hline foreglance & 1825 & Lit Rem $2: 126$ \\
\hline fore-grounded & 1819 & Notebooks 3:4498; not in OED (McKusick) \\
\hline forethoughtful & 1818 & Friend $(C C) 1: 489$ \\
\hline fossilism & 1797 & Letters (1956) 1:320 \\
\hline fountaincy & 1814 & $\begin{array}{l}\text { Letlers (1956) } 3: 518 ; \text { not in } O E I) \\
\quad \text { (McKusick) }\end{array}$ \\
\hline friendism & 1818 & $\begin{array}{l}\text { Lects on Lit (CG) } 2: 287 \text {; antedates } O E D \\
\quad[1820 \mathrm{STC}]\end{array}$ \\
\hline Gallo-barbarism & 1813 & $\begin{array}{l}\text { Notes Theological 142; not in } O E D \\
\quad \text { (McKusick) }\end{array}$ \\
\hline generalific & 1825 & $A R(1848) 1: 178$ \\
\hline generalizable & $1817-25$ & Marginalia $(C C) 1: 337$ \\
\hline generic image & 1817 & Biographia (CC) 1:94 (Hall) \\
\hline generic term & 1818 & $\begin{array}{l}\text { Notebooks 3:4445; antedates } O E D[1821] \\
\quad \text { (Shapiro) }\end{array}$ \\
\hline
\end{tabular}




\begin{tabular}{|c|c|c|}
\hline gnathonism & $1823-33$ & Marginalia $(C C)$ 2:930 \\
\hline goddage & 1826 & Notebooks 4:5410; not in $O E D$ \\
\hline godkin & 1802 & Letters (1956) 2:865 \\
\hline goëtography & $1825-26$ & Notebooks 4:5300; not in $O E D$ \\
\hline goodiness & 1808 & $\begin{array}{l}\text { Lects on Lit }(C C) 1: 108 ; \text { antedates } O E D \\
\quad[1810 \mathrm{STC}]\end{array}$ \\
\hline graspless & 1794 & $\begin{array}{l}\text { "Lines on Friend Who Died of Fever" } \\
\text { line } 43 \text { in } P W(1912) 1: 77\end{array}$ \\
\hline gratitudinarian & 1794 & Letters $(1956) 1: 83$ \\
\hline Greekist & 1796 & Letters (1956) 1:262 \\
\hline greenery & 1797 & $\begin{array}{l}\text { "Kubla Khan" line } 11 \text { in } P W(1912) 1: 297 \\
\text { (Neumann) }\end{array}$ \\
\hline gutturize & 1832 & $T T(C C) 2: 173$ \\
\hline gymnosoph & a1834 & Lit Rem 4:282 \\
\hline half-truthmen & 1832 & Letters (1956) 6:884 \\
\hline hëautepithymy & 1819 & Notebooks 4:4534; not in $O E D$ \\
\hline heautophany & al 834 & Notes on English Divines (1853) 1:257 \\
\hline Hermetist & 1817 & $\begin{array}{l}\text { Biographia }(C C) 1: 247 \text {; antedates } O E D \\
\quad[1827-48] \text { (Hall) }\end{array}$ \\
\hline heroiglyphic & 1825 & $\begin{array}{l}\text { Letters (1956) } 5: 499 ; \text { not in } O E D \\
\quad \text { (McKusick) }\end{array}$ \\
\hline heterocosmite & 1830 & $C \mathcal{E}^{\circ} S(C C) 174 ;$ not in $O E D$ (McKusick) \\
\hline heterogorize & 1820 & Notebooks $4: 4711 ;$ not in $O E D$ \\
\hline heterozetesis & 1817 & $\begin{array}{l}\text { Biographia (CC) } 1: 142 ; 1822 \text { Notebooks } \\
\text { 4:4909; not in } O E D \text { (Hall) }\end{array}$ \\
\hline heuristic & 1820 & $\begin{array}{l}\text { Notebooks 4:4656; antedates } O E D[1821 \\
\quad \text { STC] }\end{array}$ \\
\hline hierolatry & $1814-25$ & Marginalia (CC) 1:297, 2:663 \\
\hline high-treasonist & 1796 & Letters (1956) 1:259 (OED, s.v. treasonist) \\
\hline hindward & 1797 & $\begin{array}{l}\text { "Sonnet on Ruined House" line } 12 \text { in } P W \\
\text { (1912) 1:211 }\end{array}$ \\
\hline historicism & 1825 & Notebooks 4:5201; antedates $O E D[1895]$ \\
\hline home-like & 1817 & Biographia $(C C) 1: 206 \mathrm{n}$ \\
\hline housemate & 1809 & Friend ( $C C) 2: 28$ \\
\hline humanism & 1812 & Lit Rem 1:377 (Neumann) \\
\hline humorific & 1818 & Lit Rem $1: 136$ \\
\hline humoristic & 1818 & Lects on Lit (CC) $2: 177$ \\
\hline hyperclimax & 1817 & Biographia (CC) 2:123 \\
\hline hyperlatinistic & 1804 & $\begin{array}{l}\text { Marginalia }(C C) 1: 762 ; \text { antedates } O E D \\
\quad \text { [1819 STC] }\end{array}$ \\
\hline hyperstoic & 1817 & Biographia $(C C) 1: 159$ \\
\hline hypertrophic & 1832 & Blackw Mag 31 (1832): 956 \\
\hline hypochondrist & 1812 & In Southey's Omniana 2:15 \\
\hline hypopoiesis & 1809 & $\begin{array}{l}\text { Notebooks } 3: 3587 ; 1817 \text { Biographia }(C C) \\
1: 102 ; \text { not in } O E D\end{array}$ \\
\hline hypopoiesy & 1809 & Notebooks 3:3587; not in OED (McKusick) \\
\hline hypophysics & 1812 & Lit Rem $1: 349$ \\
\hline
\end{tabular}




\begin{tabular}{|c|c|c|}
\hline hypostatize & 1809 & $\begin{array}{l}\text { Friend }(C C) 2: 75 ; 1817 \text { Biographia }(C C) \\
\quad 1: 204\end{array}$ \\
\hline hypsonomy & 1822 & Notebooks $4: 4862 ;$ not in $O E D$ \\
\hline ice-fall & 1802 & $\begin{array}{l}\text { "Hymn before Sunrise" line } 49 \text { in } P W \\
\text { (1912) } 1: 379\end{array}$ \\
\hline ice-glazed & 1813 & Remorse 2.1 .18 in $P W(1912) 2: 835$ \\
\hline idea-pot & 1796 & Letters $(1956) 1: 184$ \\
\hline ideation & 1818 & $\begin{array}{l}\text { Notebooks } 3: 4445 ; \text { antedates } O E D[1829] \\
\quad(\text { Shapiro) }\end{array}$ \\
\hline idioticon & 1813 & $\begin{array}{l}\text { Lects on Lit }(C C) 1: 573 \text {; antedates } O E D \\
\quad[1842]\end{array}$ \\
\hline idiozoic & 1822 & Notebooks $4: 4910 ;$ not in $O E D$ \\
\hline illeism & 1809 & Friend (CC) 2:32; 1811 EOT (CC) 2:306 \\
\hline illuminize & 1800 & Letters (1956) 1:563 \\
\hline imaginability & 1830 & $C \mathcal{E S S}(C C) 180$ \\
\hline imbrutement & 1809 & $\begin{array}{l}\text { Notebooks 3:3568; antedates } O E D \text { [al } 837] \\
\quad \text { (Shapiro) }\end{array}$ \\
\hline imitatress & 1818 & Lects on Lit (CC) $2: 219$ \\
\hline immanence & 1816 & Lay Serm (CC) 65 (Neumann) \\
\hline impossibilification & 1818 & Lects on Lit $(C C) 2: 96$ \\
\hline improgressive & 1817 & $\begin{array}{l}\text { Biographia (CC) } 2: 137 ; 1818 \text { Friend (CC) } \\
1: 473\end{array}$ \\
\hline impurpling & 1793 & $\begin{array}{l}\text { "Songs of Pixies" line } 104 \text { in } P W(1912) \\
\text { 1:44 (OED, s.v. empurpling) }\end{array}$ \\
\hline inappellable & 1825 & $A R(1848) 1: 180$ \\
\hline inappertinent & 1814 & $\begin{array}{l}\text { Princ Genial Crit in Biographia (1907) } \\
\quad 2: 220\end{array}$ \\
\hline inappetent & 1796 & Letters (1956) 1:251 \\
\hline inaugurator & al 834 & $\begin{array}{l}\text { In Joseph Worcester, Univ } \& \text { Crit Dict } \\
\text { (1846) }\end{array}$ \\
\hline incausative & 1829 & Lit Rem 4:3 \\
\hline incelebrity & 1809 & Marginalia (CC) 1:220 \\
\hline incoherentic & $1817-18$ & Marginalia $(C C) 1: 780 ;$ not in $O E D$ \\
\hline incoincidence & 1798 & Letters (1956) 1:410 \\
\hline incorrespondency & 1817 & Biographia $(C C)$ 2:78 \\
\hline incorresponding & a1834 & In Joseph Worcester, Univ $\hat{\sigma}^{2}$ Crit Diat \\
\hline indecomponible & 1818 & Friend $(C G) 1: 470$ \\
\hline indifferential & 1818 & Lit Rem $3: 172$ \\
\hline inenergetic & 1820 & Letters (1956) 5:32 \\
\hline inexpression & 1796 & Letters (1956) 1:259 \\
\hline inferiorize & al 834 & Lit Rem $4: 238$ \\
\hline infernalise & 1817 & $\operatorname{EOT}(C G) 2: 477$ \\
\hline infidelical & 1802 & Letters (1956) 2:824 \\
\hline infidelism & a 1834 & Lit Rem 4:231 \\
\hline influencive & 1809 & $\operatorname{EOT}(C G) 2: 55$ \\
\hline inobtrusive & 1796 & $\begin{array}{l}\text { "Refl having left place Retirem" line } 23 \text { in } \\
\quad P W(1912) 1: 107\end{array}$ \\
\hline
\end{tabular}




\begin{tabular}{|c|c|c|}
\hline inquaintance & 1825 & Letters (1956) 5:466; PW (1912) 2:1012 \\
\hline in ruption & 1809 & Friend $(C C) 2: 164$ \\
\hline inrush & 1817 & Lay Serm $(C C) 159$ \\
\hline insanocaecity & 1804 & $\begin{array}{l}\text { Letters (1956) 2:1072; not in } O E D \\
\quad \text { (McKusick) }\end{array}$ \\
\hline insective & a1834 & Fraser's Mag 12 (1835): 496 \\
\hline instillator & 1830 & Marginalia $(C G) 1: 812$ \\
\hline instinctivity & 1824 & $\begin{array}{l}\text { Notebooks 4:5168; antedates } O E D[1830 \\
\text { STC] }\end{array}$ \\
\hline in-striving & 1825 & Notebooks $4: 5249 ;$ not in $O E D$ \\
\hline insusceptibility & 1821 & Blackw Mag 10 (1821): 249 \\
\hline intellectualize & c1819 & Lit Rem 2:131 \\
\hline intensify & 1817 & $\begin{array}{l}\text { Biographia (CC) } 1: 127 \mathrm{n} ; 1820 \text { Notebooks } \\
\quad 4: 4718 \text { (Neumann) }\end{array}$ \\
\hline interadditive & 1819 & Lit Rem $2: 147$ (Neumann) \\
\hline inter-breathings & a 1834 & Notes $\mathcal{G}^{2}$ Lects upon Shakespeare (1874) 318 \\
\hline intercirculation & $1814-24$ & Marginalia $(C C) 2: 666$ \\
\hline interdependence & 1821 & $\begin{array}{l}\text { Letters (1956) 5:156; AR (1825), app. C } \\
\quad \text { (Neumann) }\end{array}$ \\
\hline interdependent & 1817 & Biographia $(C C) 1: 119$ \\
\hline interfluence & 1817 & Lay Serm (CC) 160n (Neumann) \\
\hline interfusion & 1817 & Biographia (CC) 2:72 (Neumann) \\
\hline interjacentic & 1824 & Notebooks 4:5103; not in $O E D$ \\
\hline interlapidate & 1814 & $\operatorname{EOT}(C C) 2: 392$ \\
\hline intermundium & 1812 & $\begin{array}{l}\text { Lit Rem } 1: 331 ; 1817 \text { Biographia }(C C) 1: 32 \\
\text { (Neumann) }\end{array}$ \\
\hline interpenetrancy & 1822 & Notebooks $4: 4884 ;$ not in $O E D$ \\
\hline interpenetrate & 1818 & Friend (CC) 1:95, 1:517 (Neumann) \\
\hline interpenetratively & a1834 & Lit Rem 4:197 \\
\hline interramification & 1825 & $A R(1825)$, app. C 404 (Neumann) \\
\hline intersilentium & 1823 & Notebooks 4:5078; not in $O E D$ \\
\hline intertanglement & 1817 & Lay Serm (CC) 127 (Neumann) \\
\hline intertrude & 1809 & Letters (1956) 3:266 (Neumann) \\
\hline intortillage & 1809 & Let. in Sotheby's Catalogue (1896) \\
\hline intropulsive & 1825 & $A R(1858) 1$, app. C 408 \\
\hline inverisimilitude & $1809-10$ & $\begin{array}{l}\text { Notebooks 3:3654; antedates } O E D \text { [a1834 } \\
\text { STC] (Shapiro) }\end{array}$ \\
\hline inverminate & 1830 & $\operatorname{Cos}(C C) 174$ \\
\hline iotism & $1819-27$ & Notebooks 4:4636; not in $O E D$ \\
\hline iron-founder & 1817 & Lay Serm (CC) 157 \\
\hline irradiative & al 834 & Lit Rem 4:433 \\
\hline irrebuttable & a1834 & Lit Rem 3:218 \\
\hline irreferable & 1810 & Lit Rem 3:312 \\
\hline irremissive & 1817 & Biographia $(C C) 2: 16$ \\
\hline I-ship & al 834 & Lit Rem 4:232 \\
\hline Jesuitry & 1832 & $T T(C C) 1: 314$ \\
\hline juspublicist & 1810 & Friend $(C C) 2: 322$ \\
\hline ladyhood & 1820 & Letters (1956) 5:38 \\
\hline
\end{tabular}




\begin{tabular}{|c|c|c|}
\hline Lambethism & 1820 & $\begin{array}{l}\text { Marginalia (CC) 1:358; not in } O E D \\
\text { (McKusick) }\end{array}$ \\
\hline lampad & 1796 & $\begin{array}{l}\text { "Ode Departing Year" line } 76 \text { in } P W \\
\text { (1912) } 1: 164\end{array}$ \\
\hline land-taster & 1817 & Lay Serm (CC) $218 ;$ not in $O F I)$ \\
\hline latence & 1794 & $\begin{array}{l}\text { "Destiny of Nations" line } 24 \text { in } P W(1912) \\
1: 132\end{array}$ \\
\hline Laudism & 1820 & Marginalia (CC) $1: 358$ \\
\hline leading principle & 1817 & Biographia (CC) 2:115; not in OED (Hall) \\
\hline leggery & 1830 & $\cos (C O) 175$ \\
\hline legisprudence & 1830 & CoS (CG) $33 ;$ not in OED \\
\hline Lichen Geographicus & 1823 & Notebooks $4: 4984 ;$ not in $O E D$ \\
\hline lignify & 1814 & $\begin{array}{l}\text { Letters (1956) 3:519; antedates OED) } \\
\text { [1828] (McKusick) }\end{array}$ \\
\hline lingua communis & 1817 & $\begin{array}{l}\text { Biographia (CC) 1:210,2:56; not in OEL } \\
\text { (Hall) }\end{array}$ \\
\hline linguipotence & $1817-25$ & Marginalia $(C C) 2: 317$ \\
\hline literata & 1794 & Letlers (1956) 1:109 \\
\hline live-asunder & 1817 & $\begin{array}{l}\text { Lay Serm (CC) 182: antedates OED [a } 1834 \\
\text { STC] }\end{array}$ \\
\hline logico-obstetric & 1810 & Lit Rem $3: 383$ \\
\hline logolatry & 1810 & Lit Rem 4:305 \\
\hline logomachist & 1825 & Lit Rem 4:272 (Neumann) \\
\hline logosophia & 1815 & $\begin{array}{l}\text { Letlers (1956) 4:589; not in } O E L) \\
\quad(\text { Neumann) }\end{array}$ \\
\hline longanimity & 1821 & Notebooks $4: 4800 ;$ not in $O E D$ \\
\hline lumberly & 1805 & Letters (1956) 2:1161 \\
\hline lumpet & 1812 & Lit Rem $1: 366$ \\
\hline magazinish & 1794 & Letters (1956) $1: 141$ \\
\hline malafiges & 1807 & $\begin{array}{l}\text { Notebooks 2, app. F: antedates } O E L) \\
\text { (Shapiro) }\end{array}$ \\
\hline Mammonolatry & al 824 & Marginalia (CG) $1: 307$ \\
\hline man-worthy & 1830 & $\begin{array}{l}\text { CES(C:C) 16; antedates } O E D \text { lal834 } \\
\text { STC: }\end{array}$ \\
\hline marginalia & 1830 & $\cos (c c) 166 ; 1832$ Letters (1956) 6:901 \\
\hline master-thought & 1817 & Biographia (CC) $1: 297$; not in $O E D$ (Hall) \\
\hline meadow-gale & 1798 & $\begin{array}{l}\text { Ancient Mariner line } 457 \text { in } P W(1912) \\
1: 204\end{array}$ \\
\hline mechanico-corpuscular & 1825 & $A R(1848) 1: 327$ \\
\hline meerschaum & 1799 & Lelters (1956) 1:463 (Neumann) \\
\hline mesothesis & 1829 & $\begin{array}{l}\text { Letters (1956) 6:818; } 1830 \text { Marginalia (CC) } \\
\quad 1: 806 \text { (Neumann) }\end{array}$ \\
\hline Messianic & $1827-31$ & Marginalia (CC) $1: 708$ \\
\hline meta-grammatic & $1820-21$ & Notebooks 4:4771; not in $O E D$ (McKusick) \\
\hline metapolitician & 1809 & Friend (CC) 2:106n \\
\hline miarchist & 1819 & Notebooks 4:4514; not in (OED \\
\hline micranthropos & 1825 & $A R(1825) 389$ \\
\hline minimifidian & 1825 & $A R(1848) 1: 164$ \\
\hline
\end{tabular}




\begin{tabular}{|c|c|c|}
\hline minimism & 1819 & Letters (1956) 4:969 \\
\hline Minnesinger & 1817 & $\begin{array}{l}\text { Biographia (CC) 1:209; antedates } O E D \\
\quad[1825 \text { STC] (Neumann) }\end{array}$ \\
\hline miscopied & 1825 & Lit $\operatorname{Rem} 2: 324$ \\
\hline Misogyne & 1817 & Biographia $(C C)$ 1:229 \\
\hline misology & 1833 & $T T(C C) 1: 338($ Neumann) \\
\hline misosophy & $1824-26$ & Marginalia ( $C C$ ) 2:1147 (Neumann) \\
\hline misothelesia & 1819 & Notebooks $4: 4566 ;$ not in $O E D$ \\
\hline misproportion & 1825 & $A R(1848) 1: 213$ \\
\hline mis-script & al 834 & $\begin{array}{l}\text { Notes } \mathcal{F}^{2} \text { Lects upon Shakespeare (1849) } \\
1: 143\end{array}$ \\
\hline modifiability & 1827 & $T T(C C) 1: 68 ;$ antedates $O E D[1840]$ \\
\hline momenteity & 1820 & Notebooks $4: 4662 ;$ not in $O E D$ \\
\hline monodize & 1796 & Letters (1956) 1:230 \\
\hline mononomian & c1810 & Lit Rem 3:307 \\
\hline monophthalmic & 1820 & Notebooks 4:4748; antedates $O E D$ [1857] \\
\hline monosyllabically & 1816 & Letters (1956) 4:642 \\
\hline moonery & a1834 & Blackw Mag 131 (1882): 119 \\
\hline motiunculae & 1816 & Lay Serm $(C C) 80$; not in $O E D$ (McKusick) \\
\hline mouthishly & 1798 & Letters (1956) $1: 357$ \\
\hline multeity & 1814 & $\begin{array}{c}\text { Princ Genial Crit in Biographia (1907), 2:232; } \\
1817 \text { Biographia (CC) 1:287 (Neumann) }\end{array}$ \\
\hline multiscience & a1834 & Lay Serm $(C C) 26 \mathrm{n}$ \\
\hline multivocal & 1823 & $\begin{array}{l}\text { Notebooks } 4: 4938,4: 5398 ; 1826 \text { Marginalia } \\
\quad \text { (CC) } 2: 1160\end{array}$ \\
\hline musculo-arterial & 1825 & $A R(1848) 1: 85$ \\
\hline myriad-minded & 1816 & $\begin{array}{l}\text { Lay Serm (CC) 79; } 1817 \text { Biographia }(C C) \\
\text { 2:19 (Neumann) }\end{array}$ \\
\hline myriotheism & 1823 & Marginalia (CC) 2:924 \\
\hline mythically & 1817 & Biographia (CC) 1:157 (Hall) \\
\hline mythus & a1834 & Lit Rem 2:335 \\
\hline nasoductility & $1817-25$ & Marginalia (CC) 1:332 \\
\hline nationalty & 1830 & $\begin{array}{l}\operatorname{CES}(C C) 35 ; 1831-32 \text { Marginalia }(C C) \\
2: 294\end{array}$ \\
\hline naturiency & 1822 & Notebooks $4: 4894 ;$ not in $O E D$ \\
\hline necrozoic & 1819 & Notebooks $4: 4617$; not in $O E D$ \\
\hline negativity & 1826 & Notebooks 4:5416; antedates $O E D$ [1854] \\
\hline neurolepsia & 1822 & Notebooks $4: 4910 ;$ not in $O E D$ \\
\hline neuro-pathology & a1834 & $\begin{array}{l}\text { Inquiring Spirit no. 40; antedates } O E D \\
\quad[1853]\end{array}$ \\
\hline non-absolute & 1830 & $\operatorname{TT}(C C) 1: 106$ \\
\hline non-sympathy & 1833 & $T T(C C) 1: 342$ \\
\hline nugifying & 1823 & Marginalia $(C G)$ 2:295 \\
\hline nunhood & 1812 & Lit Rem $4: 69$ \\
\hline o'er-gloom & 1795 & $\begin{array}{l}\text { "To Author Poems Publ Bristol" line } 20 \\
\text { in } P W(1912) 1: 103\end{array}$ \\
\hline o'er-wooded & 1797 & $\begin{array}{l}\text { "Lime-tree Bower" line } 10 \text { in } P W(1912) \\
1: 179\end{array}$ \\
\hline
\end{tabular}




\begin{tabular}{|c|c|c|}
\hline obitaneously & a1834 & Confess Enq Spirit (1840) 18 \\
\hline obtrusively & 1817 & Biographia (CC) 1:197 (Hall) \\
\hline ocularity & 1823 & Notebooks $4: 5086 ;$ not in $O E D$ \\
\hline off-sloping & 1797 & Osorio 2.148 in $P W(1912) 2: 541$ \\
\hline oligosyllabic & 1830 & $T T(C C) 2: 77$ \\
\hline omening & 1796 & Letters (1956) 1:226 \\
\hline on-carryingness & 1830 & Letters (1956) 6:911 \\
\hline operancy & 1810 & Lit Rem 3:303 \\
\hline ordonnant & 1818 & $\begin{array}{l}\text { Lects on Lit (CC) 2:75; antedates } O E D \\
\quad[1820-30 \mathrm{STC}]\end{array}$ \\
\hline organic whole & 1817 & $\begin{array}{l}\text { Biographia }(C G) 1: 234 \text { (Hall); } 1825 A R \\
\quad \text { (1913) } 108\end{array}$ \\
\hline orthodoxist & 1816 & $\begin{array}{l}\text { Notebooks 3:4312; antedates OED [1857] } \\
\quad \text { (Shapiro) }\end{array}$ \\
\hline otherworldliness & 1834 & $\begin{array}{l}\text { Lets, Convs, } \mathcal{F}^{2} \text { Recs (1836) 1:98-99 } \\
\text { (Neumann) }\end{array}$ \\
\hline ourishness & 1819 & Lects on Lit $(C C) 2: 363$ \\
\hline outbeam & 1797 & Letters (1956) 1:330 \\
\hline out-shadowings & 1825 & $A R(1848) 1: 292$ \\
\hline overbillowed & 1814 & Letters (1956) 3:522 \\
\hline overhugely & 1807 & Letters (1956) 3:42 \\
\hline pacable & 1830 & $C \mathcal{G S S}(C C) 154$ \\
\hline panaceist & 1803 & Letters (1956) 2:988 \\
\hline pantisocratic & 1794 & Letters (1956) 1:103 \\
\hline pantoiomathy & 1819 & Notebooks 4:4617; not in $O E D$ \\
\hline papoduly & $1812-34$ & Marginalia $(C C) 2: 38 ;$ not in $O E D$ \\
\hline papophobists & $1823-33$ & Marginalia (CC) 2:935; not in $O E D$ \\
\hline parrotry & 1796 & Watchman $(C C) 122 \mathrm{n}$ \\
\hline parthenolatry & c1823 & $\begin{array}{l}\text { Marginalia (CG) } 2: 916 ; 1825 \text { Notebooks } \\
\quad 4: 5240 \text { (Neumann) }\end{array}$ \\
\hline particularism & 1824 & Marginalia (CC) 2:674 \\
\hline pedoeuvre & 1815 & $A R(1825) 212 ; 1822$ Notebooks $4: 4884$ \\
\hline performant & 1809 & Letters (1956) 3:171 \\
\hline perfusive & 1817 & Biographia (CC) 2:34 \\
\hline peripheric & 1818 & Friend $(C C) 1: 427 \mathrm{n}$ \\
\hline personeity & 1822 & Letters (1956) 5:252; 1825 Notebooks $4: 5215$ \\
\hline pessimism & 1794 & Letters (1956) 1:139 (Neumann) \\
\hline phantasmist & 1823 & $T T(C C) 2: 39$ \\
\hline phantomatic & 1818 & Lects on Lit (CC) $2: 428$ \\
\hline phenomenal & 1825 & $A R(1848) 1: 205$ (Neumann) \\
\hline philagathy & 1823 & Notebooks 4:5094; not in $O E D$ \\
\hline philalethist & 1821 & Notebooks 4:4809; not in $O E D$ \\
\hline philalethy & 1823 & Notebooks 4:5094; not in $O E D$ \\
\hline philepistasy & 1824 & Notebooks $4: 5132 ;$ not in $O E D$ \\
\hline philonoists & 1804 & $\begin{array}{l}\text { Letters (1956) 2:1032; } 1823 \text { Notebooks } \\
\quad 4: 5078\end{array}$ \\
\hline philonöy & 1823 & Notebooks $4: 5080 ;$ not in $O E D$ \\
\hline
\end{tabular}


philosophicide

philosophistic

philotechnist

philotheorist

phisiophilist

photöid

phraseman

physiogonist

physiogony

physiography

physiopathic

physiosophy

phytic

phytoid

phytozoic

pingui-nitescent

planless

playless

plebification

pleistodox

pluminess

poematic

polymerea

post-prandial

potenziate

potenziated

potenziation

practical criticism

praeternational

preattune

precant

preconcertedness

precondition

preconfigure

preconformity

preconstituent

preconstruction

predestinative
$1804 \quad$ Letters (1956) 2:1072

$1810 \quad$ Notebooks 3:3816; antedates OED [1828] (Shapiro)

1818 Friend (CC) $1: 472$

1818 Friend ( $C C)$ 1:472 (OED, s.v. philotechnic)

$1804 \quad$ Letters (1956) 2:1032

1822-27 Notebooks 4:4929; not in OED

1798 "Fears in Solitude" line 111 in $P W(1912)$ $1: 260$

1821-22 Notebooks 4:4843; not in OED

$1824 \quad$ Notebooks 4:5144; antedates $O E D$ [a1834 STC]

1825 Notebooks 4:5232; antedates OED [182832]

$1800 \quad$ Letters (1956) 1:588

$1816 \quad$ Letters (1956) 4:654; antedates OED [1886] (McKusick)

1822 Notebooks 4:4862; antedates $O E D$ [1908]

1822-27 Notebooks 4:4929; antedates OED [1858]

1819 Notebooks 4:4617; not in OED

1817 Biographia (CC) 1:180

$1800 \quad$ Piccolom 4.4.40 in $P W$ (1912) 2:691

al834 In Noah Webster, Am Dict (1864)

1818 Friend (CC) 1:447

$1814 \quad$ Letters (1956) 3:466

$1802 \quad$ Letters (1956) 2:882

1819 Lit Rem 2:321

1824 Notebooks 4:5181; antedates $O E D$ [s.v. polymery]

1820 Letters (1956) 5:12 (Neumann)

1817 Biographia (CC) 1:287 (Neumann)

1819 Lects on Lit (CC) 2:374

1820 Notebooks 4:4645; antedates $O E D$ [1840]

1817 Biographia (CC) 2:19; 1818 Lects on Lit (CC) 2:34; antedates OED [1929]

$1814 \quad$ Letters (1956) 3:518; not in OED

(McKusick)

$1794 \quad$ Ietters (1956) 1:89

a1834 Lit Rem 4:38

$1818 \quad$ Lects on Lit (CC) 2:284

$1825 \quad A R(1848) 1: 36$

$1809 \quad$ Friend (CC) 2:100

$1825 \quad A R(1848) 1: 186$

1816 Lay Serm (CC) 104

al 834 Theory of Life (1848) 87; not in OED

(McKusick)

1831 Marginalia (CC) 1:827 


\begin{tabular}{|c|c|c|}
\hline predeterminable & a 1834 & Fraser's Mag 12 (1835): 620 \\
\hline pre-enacted & 1825 & $A R(1848) 1: 298$ \\
\hline presentimental & 1818 & $\begin{array}{l}\text { Lects on Lit (CC) 2:307; antedates OED } \\
\quad[\text { c1819 STC] }\end{array}$ \\
\hline probabilize & 1804 & $\begin{array}{l}\text { Notebooks 1:1826; antedates } O E D) \\
\quad[1802-12] \text { (Shapiro) }\end{array}$ \\
\hline prodocimastic & 1826 & Notebooks $4: 5443 ;$ not in $O E I$ \\
\hline productivity & 1818 & Friend (CC) $1: 514$ (Neumann) \\
\hline proflated & 1817 & Biographia (CC) $2: 226$ \\
\hline promptress & 1793 & "To Fortune" line I in $P W(1912) 1: 55$ \\
\hline proprietage & 1830 & $\operatorname{Cos}(C C) 108$ \\
\hline proschema & 1820 & Notebonks $4: 4656$; not in $O E D$ \\
\hline prosish & 1797 & Letters (1956) 1:334 \\
\hline prosist & 1809 & Letters (1956) $3: 266$ \\
\hline prospectivencss & 1817 & Biographia (CC) 2:58 \\
\hline protonomy & 1822 & Notebooks $4: 4862 ;$ not in $O E D$ \\
\hline protozoa & 1825 & AR (1839) 64; 1825 Votebooks $4: 5266$ \\
\hline provisionless & 1796 & $\begin{array}{l}\text { "Destiny of Nations" linc } 243 \text { in } P W \\
\text { (1912) } 1: 139\end{array}$ \\
\hline prudentialist & 1830 & Marginalia (CC) 1:812 \\
\hline pseudography & 1822 & Notebooks 4:4910; not in $O E D$ \\
\hline pseudo-poetic & 1817 & Biographia (CC) $1: 39$ \\
\hline psilanthropic & a1834 & Lit Rem $4: 13$ \\
\hline psilanthropism & 1810 & Lit Rem 3:260; 1817 Biographia (CC) 2:246 \\
\hline psilanthropist & $\mathrm{c} 1810$ & $\begin{array}{l}\text { Lit Rem } 3: 241 ; 1817 \text { Biographia (CC) 1:180 } \\
\quad \text { (Neumann) }\end{array}$ \\
\hline psilology & $1824-26$ & Marginalia (CC) 2:1147 \\
\hline psilosopher & $1808-11$ & $\begin{array}{l}\text { Notebooks } 3: 3244 ; \text { antedates } O E D \text { [ }[1882] \\
\quad \text { (Shapiro) }\end{array}$ \\
\hline psilosophy & 1809 & $\begin{array}{l}\text { EOT (CC) 2:80; antedates OED }[1817 \\
\text { STC: }\end{array}$ \\
\hline psychal & $1822-25$ & Notebooks 4:4935; antedates $O E D$ [1844] \\
\hline psycho-analytical & 1805 & $\begin{array}{l}\text { Notebooks 2:2670; antedates } O E D[1857] \\
\text { (Shapiro) }\end{array}$ \\
\hline psychologize & 1810 & $\begin{array}{l}\text { Notebooks 3:3994; antedates OED [18:30] } \\
\text { (Shapiro) }\end{array}$ \\
\hline psycho-somatic & c1812 & $\begin{array}{l}\text { Inquiring Spirit no. 52; antedates OED } \\
\quad[1863]\end{array}$ \\
\hline puncturient & 1823 & Notebooks 4:4974; not in OFD \\
\hline punlet & 1819 & Lit Rem 2:287 \\
\hline pun-maggot & 1819 & Lit Rem $2: 287$ \\
\hline queen's metal & 1804 & $\begin{array}{l}\text { Notebooks 2:2026; antedates OED [1839] } \\
\quad \text { (Shapiro) }\end{array}$ \\
\hline querification & 1825 & Notebooks $4: 5189 ;$ not in $O E I$ \\
\hline rain-storm & 1816 & Lay Serm $(C C) 78$ \\
\hline re-actuate & 1810 & Lit Rem $3: 386$ \\
\hline realism & 1817 & Biographia (CC) 1:261 (Neumann) \\
\hline
\end{tabular}




\begin{tabular}{|c|c|c|}
\hline realizer & 1809 & Friend ( $C C)$ 2:86 \\
\hline recentre & 1796 & $\begin{array}{l}\text { "Ode Departing Year" line } 158 \text { in } P W \\
\text { (1912) } 1: 168\end{array}$ \\
\hline re-ebullient & 1817 & Biographia $(C C) 1: 300$ \\
\hline re-elevate & a1834 & $\begin{array}{l}\text { In Joseph Worcester, Univ E Crit Dict } \\
\text { (1846) }\end{array}$ \\
\hline re-emersion & 1801 & Letters (1956) 2:778 \\
\hline reformators & 1823 & Notebooks 4:5084; not in $O E D$ \\
\hline refuel & 1811 & Letters (1956) 3:332 \\
\hline regnancy & a1834 & Lit Rem 3:159 \\
\hline rehouse & 1820 & Letters $(1956) 5: 48$ \\
\hline reific & 1820 & Notebooks 4:4696; not in $O E D$ \\
\hline relativity & 1834 & Lit Rem 4:223 (Neumann) \\
\hline reliability & 1816 & $\begin{array}{l}\text { Letters (1956) 4:705; } 1817 \text { Biographia }(C C) \\
\quad \text { l:66 (Neumann) }\end{array}$ \\
\hline remotive & 1817 & $\begin{array}{l}\text { Notebooks 3:4328; antedates } O E D[1819] \\
\quad \text { (Shapiro) }\end{array}$ \\
\hline repullulative & 1825 & Letters (1956) 5:497 (Neumann) \\
\hline researchful & 1819 & Iit Rem 2:129 \\
\hline resurgence & 1834 & Lit Rem 2:153 (Neumann) \\
\hline resurgency & a1834 & $A R(1858)$ app. C $1: 403$ \\
\hline retrogress & 1814 & Letters (1956) 3:488 \\
\hline retroitive & 1830 & $C \mathcal{E S}(C C) 180 ;$ not in $O E D$ \\
\hline revalescence & 1810 & Lit Rem 3:301 \\
\hline revelability & 1816 & Lay Serm $(C C) 106$ \\
\hline rhematic & 1824 & $\begin{array}{l}\text { Notebooks 4:5133; antedates } O E D[1830 \\
\quad \text { STC }]\end{array}$ \\
\hline rhythmless & al834 & $\begin{array}{l}\text { In Joseph Worcester, Univ } \mathcal{G}^{2} \text { Crit Dict } \\
(1846)\end{array}$ \\
\hline ribless & 1794 & "To a Young Ass" line 30 in $P W(1912) 1: 75$ \\
\hline ridge-like & 1817 & Lay Serm $(C C) 135$ \\
\hline romanticize & 1818 & Letters (1956) 4:868 \\
\hline Rumfordize & 1796 & Letters (1956) 1:288 \\
\hline saleability & 1797 & Let. in Sotheby's Catalogue (1891) \\
\hline sapientize & c1810 & Lit Rem $3: 219$ \\
\hline scathing & 1794 & $\begin{array}{l}\text { "Monody Death Chatterton" var. of } \\
\text { line } 19 \text { in } P W(1912) 1: 128\end{array}$ \\
\hline sciolism & 1816 & $\begin{array}{l}\text { Lay Serm (CC) 94; } 1817 \text { Biographia }(C C) \\
1: 57\end{array}$ \\
\hline scious & a 1834 & Lit Rem $4: 428$ \\
\hline scribble-mania & 1792 & Letters (1956) 1:28 \\
\hline scriblerism & 1801 & Letters (1956) 2:749 \\
\hline scripturalize & 1818 & $\begin{array}{l}\text { Lects on Lit }(C C) 2: 94 ; \text { antedates } O E D \\
\quad[1858]\end{array}$ \\
\hline scytheless & 1817 & "Limbo" line 15 in $P W(1912)$ 1:430 \\
\hline seclusive & a1834 & $\begin{array}{l}\text { In Joseph Worcester, Dict of Eng Lang } \\
(1860)\end{array}$ \\
\hline
\end{tabular}




\begin{tabular}{|c|c|c|}
\hline sectarianism & 1817 & Biographia (CC) 1:247 (Hall, Neumann) \\
\hline self-acknowledged & 1809 & Friend $(C C) 2: 45$ \\
\hline self-causing & 1830 & CES (CC) $182 ;$ not in OED (McKusick) \\
\hline self-centre & $1794-96$ & $\begin{array}{l}\text { "Religious Musings" line } 91 \text { in } P W(1912) \\
1: 113\end{array}$ \\
\hline self-consoling & 1814 & $\begin{array}{l}\text { Princ Genial Crit in Biographia }(1907) \\
\quad 2: 229\end{array}$ \\
\hline self-construction & 1817 & Biographia (CC) 1:286; not in $O E D$ (Hall) \\
\hline self-containing & 1830 & $\begin{array}{l}C \mathcal{C} S(C C) 182 ; \text { antedates } O E D[1847] \\
\text { (McKusick) }\end{array}$ \\
\hline self-development & 1817 & Biographia (CC) 1:286 (Hall) \\
\hline self-dissatisfied & 1809 & Friend $(C C) 2: 11$ \\
\hline self-duplication & 1817 & Biographia (CC) $1: 273$ (Hall) \\
\hline self-evolution & 1830 & CESS (CC) 180 ; not in OED (McKusick) \\
\hline self-examinant & 1825 & $A R(1825) 164$ \\
\hline self-existential & 1820 & Letters (1956) 5:87; not in $O E D$ (McKusick) \\
\hline self-finding & 1830 & $\operatorname{CES}(C C) 180 ;$ not in $O E D$ (McKusick) \\
\hline self-grounded & 1817 & Biographia (CC) 1:268 (Hall) \\
\hline self-inspired & 1817 & Biographia (CC) $2: 59 ;$ not in $O E D$ (Hall) \\
\hline self-insufficiency & 1820 & Notebooks $4: 4730 ;$ not in $O E D$ \\
\hline self-intuition & 1817 & Biographia (CC) I:241; not in OED (Hall) \\
\hline self-involution & 1817 & Biographia (CC) 2:211 \\
\hline selfless & 1825 & $A R(1825) 83$ \\
\hline self-losing & 1830 & $\operatorname{CoS}(C C) 181 ;$ not in $O E D$ (McKusick) \\
\hline self-manifestation & a 1834 & $\begin{array}{l}\text { Fraser's Mag } 12(1835): 496 ; \text { not in } O E D) \\
\quad \text { (McKusick) }\end{array}$ \\
\hline self-organizing & 1812 & $\begin{array}{l}\text { Letters (1956) } 3: 413 ; \text { not in } O E D \\
\quad \text { (McKusick) }\end{array}$ \\
\hline self-percipience & 1820 & Notebooks $4: 4717$; not in $O E D$ \\
\hline self-retaining & 1830 & $C E S(C C) 181 ;$ not in $O E D$ (McKusick) \\
\hline self-revelation & 1818 & $\begin{array}{l}\text { Notebooks } 3: 4445 \text {; antedates } O E D \text { [1852] } \\
\quad \text { (Shapiro) }\end{array}$ \\
\hline self-torture & 1809 & Friend $(C C) 2: 49$ \\
\hline semi-adjectively & 1810 & Lit Rem $4: 368$ \\
\hline semi-conscious & 1803 & $\begin{array}{l}\text { Notebooks 1:1575; antedates } O E D[1839] \\
\quad \text { (Shapiro) }\end{array}$ \\
\hline semi-demi-conscious & 1804 & Notebooks $2: 2073$; not in $O E D$ (Shapiro) \\
\hline semi-revolutionist & 1812 & Lit Rem $1: 298$ \\
\hline sendee & 1806 & Letters (1956) 2:1175 \\
\hline sense of reality & 1809 & $\begin{array}{l}\text { Friend (CC) } 2: 176 ; 1817 \text { Biographia (CC) } \\
2: 235 ; \text { not in } O E D \text { (Hall) }\end{array}$ \\
\hline sensific & 1819 & Notebooks 4:4554; antedates $O E D$ [ 1829] \\
\hline sensuously & 1825 & $A R(1848) 1: 326$ \\
\hline sentience & 1820 & Notebooks 4:4717; antedates OED [1839] \\
\hline septemplicate & 1805 & Letters (1956) 2:1164 \\
\hline Shakspearianized & 1804 & $\begin{array}{l}\text { Notebooks 2:2274; antedates OED [1936] } \\
\text { (McKusick) }\end{array}$ \\
\hline
\end{tabular}




\begin{tabular}{|c|c|c|}
\hline sheepified & 1812 & Letters (1956) 3:391 \\
\hline shillingless & 1797 & Letters (1956) 1:327 \\
\hline sideless & 1817 & Biographia (CC) 1:271 \\
\hline Sir-Thomas-Brown-ness & 1804 & Marginalia ( $C C)$ 1:763 (OED, s.v. “-ness”) \\
\hline slipsloppish & 1797 & Letters (1956) 1:334 \\
\hline snow-fog & 1817 & $\begin{array}{l}\text { Ancient Mariner marginal note in } P W \\
\text { (1912) } 1: 189\end{array}$ \\
\hline sombring & 1825 & Notebooks 4:5215; antedates $O E D$ [1849] \\
\hline somniative & 1827 & Lit Rem $4: 422$ \\
\hline somniloquent & 1804 & Blackw Mag 131 (1882): 123 \\
\hline somniloquise & a1834 & Blackw Mag 131 (1882): 119 (McKusick) \\
\hline somniloquism & 1821 & Blackw Mag 10 (1821): 244 \\
\hline somniloquist & 1830 & Marginalia $(C C)$ 1:808 \\
\hline soothingness & 1818 & Letters (1956) 4:869 \\
\hline soul-and-bodyists & 1817 & Biographia $(C C) 1: 135$ \\
\hline soul-benumbing & 1817 & $\begin{array}{l}\text { Biographia }(C C) 2: 60-61 \mathrm{n} \text {; not in } O E D \\
\quad \text { (Hall) }\end{array}$ \\
\hline soulmate & 1821 & Letters (1956) 5:153 \\
\hline space-filling & 1817 & Biographia (CC) $1: 130$ \\
\hline spectatorate & 1802 & $E O T(C C) 1: 331 ;$ not in $O E D$ \\
\hline Spenserian & 1796 & $\begin{array}{l}\text { Preface to Sonnets in } P W(1912) 2: 1140 ; \\
\text { antedates OED [1817 STC] (McKusick) }\end{array}$ \\
\hline Spenserian stanza & 1817 & Biographia $(C C)$ 1:80 (Hall) \\
\hline Spinozistic & 1832 & $T T(C C) 1: 280$ \\
\hline stalactitious & 1799 & Letters (1956) 1:500 \\
\hline starchy & 1802 & Letters (1956) 2:819 \\
\hline statuesque & 1799 & $\begin{array}{l}\text { Letters (1956) } 1: 511 \text {; antedates } O E D \\
\text { [a1834 STC] (Neumann) }\end{array}$ \\
\hline stentorship & 1817 & Biographia $(C C)$ 2:227 \\
\hline sterilifidianism & 1830 & Marginalia $(C C) 1: 814$ \\
\hline storm-blast & 1798 & Ancient Mariner line 41 in $P W(1912) 1: 188$ \\
\hline storm-rent & 1794 & $\begin{array}{l}\text { "To a Young Lady" line } 21 \text { in } P W(1912) \\
\text { 1:65 }\end{array}$ \\
\hline straight forward & 1800 & $E O T(C C) 1: 104 ;$ antedates $O E D[1807]$ \\
\hline subadditive & 1812 & Lit Rem 1:366 \\
\hline sub-causes & 1825 & $A R(1848) 1: 184$ \\
\hline subconsciousness & 1806 & $\begin{array}{l}\text { Notebooks 2:2915; antedates } O E D[1874] \\
\text { (Shapiro) }\end{array}$ \\
\hline subintellige & 1830 & $C \operatorname{Cos}(C C) 90 ;$ not in $O E D$ \\
\hline subjectivity & 1812 & $\begin{array}{l}\text { Lit Rem 1:294 [wrongly attrib. to Southey } \\
\text { in } O E D \text { ] (McKusick) }\end{array}$ \\
\hline subject-object & 1821 & Blackw Mag 10 (1821): 249 \\
\hline subjugator & a1834 & $\begin{array}{l}\text { In Joseph Worcester, Univ } \mathcal{E}^{2} \text { Crit Dict } \\
(1846)\end{array}$ \\
\hline subscribable & 1825 & $A R(1848) 1: 310$ \\
\hline subsensuous & a1834 & $\begin{array}{l}\text { Notes } \mathcal{E}^{2} \text { Lects upon Shakespeare (1849) } \\
\text { 1:164 }\end{array}$ \\
\hline
\end{tabular}


subspeciation

substanceless

subvertible

subvestment

suffiction

suggerent

super-finite

superplanetaries

superscientific

super-sensuous

supersistent

super-tragic

supra-humanity

sure-refuged

surginess

suscipiency

syllogy

sympathist

symptomatize

synartesis

syntaxist

tabernacler

take-for-granted

tarditude

tautegorical

technique

telegraph-pole

territorialize

theanthropism

theanthropist

theletic

Theo-mammonists

Theotiscan

this-worldian

thought-bewildered

thunder-fit

time-shrouded

titubancy

toadlet
1826 Nolebooks 4:5446; antedates OED [1942]

1816 "Human Life" line 15 in PW(1912) 1:426

1817 Biographia (CC) 2:42

$1802 \quad$ Letlers (1956) 2:847

$1809 \quad$ Notebooks 3:3587; antedates OED [1817 STC] (Shapiro)

1820-21 Notebooks 4:4783; not in OED

al834 Lit Rem 4:433

1827 Blackw Mag 131 (1882): 117

$1820 \quad$ Notebooks 4:4642; antedates $O E D$ [1881]

1818 Friend (CC) $1: 156 ; 1825$ AR $1: 276$

al $834 \quad$ Lit Rem 4:161

1817 Biographin (CC) $2: 230$

c1810 Lit Rem 3:253

1794-96 "Religious Musings" line 70 in $P W(1912)$ $1: 111$

$1799 \quad$ Letters (1956) 1:510

$1822 \quad$ Notebooks 4:4908; antedates OED [1885]

1820-21 Notebooks 4:4765; Letters 5:133; not in OED

1818 Lects on Lit (CC) $2: 299$

$1794 \quad$ Letters (1956) $1: 103 ; 1817$ Biographia (CC) $1: 199$

1818 Friend ( $C G$ ) 1:94n; not in $O E D$ (McKusick)

al $834 \quad$ Notes $\mathcal{E}$ Lects upon Shakespeare (1849) 1:151

$1810 \quad$ Lit Rem 4:371

$1833 \quad$ Letters (1956) 6:933

$1794 \quad$ Letters (1956) 1:106

1816 Lay Serm (CC) 30; 1820 Notebooks 4:4711; antedates $O E D$ [1825 STC]

1817 Biographia (CC) 1:79 (Neumann)

$1808 \quad$ Notebooks 3:3384; antedates OED [1851] (Shapiro)

1819 Lects on Lit (CC) 2:400

1817 Biographia (CC) 2:946 (Neumann)

$1807 \quad$ Notebooks 2:3022; antedates OED [1816] (Shapiro)

$1819 \quad$ Nolebooks 4:4591; not in OED

$1804 \quad$ Letters (1956) 2:1042

1817 Biographia (CG) 1:209 (Hall)

$1830 \quad$ CES (CC) 74

$1807 \quad$ Letters (1956) 3:23

1798 Ancient Mariner line 69 in PW (1912) 1:189

1794 "Monody Death Chatterton" line 163 in $P W(1912) 1: 131$

$1800 \quad$ Letters (1956) 1:580 (Neumann)

1817 Biographia (CC) 2:178:1834 TT (CC) 1:485 


\begin{tabular}{|c|c|c|}
\hline totalize & 1818 & Lects on Lit $(C G) 2: 221$ \\
\hline toto orbe & al 834 & Lit Rem 4:232 \\
\hline tough-lived & 1825 & Letters (1956) 5:497 \\
\hline toxication & 1821 & Blackw Mag 10 (1821): 243 \\
\hline trans-conceive & 1833 & Marginalia $(C C) 2: 882 ;$ not in $O E D$ \\
\hline trans-create & al 834 & Lit Rem 4:166 \\
\hline transcreation & 1820 & Notebooks $4: 4728 ;$ not in $O E D$ \\
\hline transimagine & 1833 & Marginalia (CC) 2:882; not in $O E D$ \\
\hline transinfusion & $1809-10$ & Marginalia (CC) $2: 250$; not in $O E D$ \\
\hline transitional & c1810 & Lit Rem 3:262 \\
\hline transmutual & 1829 & Marginalia (CC) 1:340 \\
\hline transnihilation & 1818 & Friend $(C C) 1: 522 \mathrm{n}$ \\
\hline transprint & 1825 & $A R(1848) 1: 337$ \\
\hline trans-realization & a1834 & $\begin{array}{l}\text { Marginalia to Schelling in Biographia } \\
\text { (1847) 1:303; not in OED (McKusick) }\end{array}$ \\
\hline transsensual & 1807 & Marginalia (CC) 2:802 \\
\hline transuterine & 1830 & $C \mathcal{O} S(C C) 176$ \\
\hline tremendity & 1796 & Notebooks $1: 174 ;$ not in $O E D$ (Neumann) \\
\hline trocheized & al 834 & $\begin{array}{l}\text { Notes } \mathcal{F}^{\circ} \text { Lects upon Shakespeare (1849) } \\
\text { 1:319 }\end{array}$ \\
\hline tuism & 1796 & Watchman (CC) 56; 1809 Friend (CC) 2:32 \\
\hline twy-cluster'd & $? 1825-26$ & $\begin{array}{l}\text { "Pang More Sharp" line } 13 \text { in } P W(1912) \\
1: 458\end{array}$ \\
\hline twy-streaming & $1794-96$ & $\begin{array}{l}\text { "Religious Musings" line } 204 \text { in } P W \\
\text { (1912) } 1: 116\end{array}$ \\
\hline ultra-crepidation & 1800 & Letters (1956) 1:632 (Neumann) \\
\hline Ultra-fidianism & 1825 & $A R(1825) 8$ \\
\hline ultra-human & 1818 & Lit Rem $1: 185$ \\
\hline ultra-idealist & 1821 & $\begin{array}{l}\text { Blackw Mag } 10 \text { (1821): } 249 ; \text { not in } O E D \\
\quad \text { (McKusick) }\end{array}$ \\
\hline ultra-Spartan & 1832 & $T T(C C) 1: 326$ \\
\hline unalphabeted & 1799 & Letters (1956) 1:528 \\
\hline unarbitrariness & 1825 & Lit Rem $2: 359$ \\
\hline unauthorish & 1798 & Letters (1956) 1:413 \\
\hline unbellerophontic & 1804 & Letters (1956) 2:1078 \\
\hline unbirdlimed & 1800 & Letters $(1956) 1: 587$ \\
\hline unbrightened & 1827 & $\begin{array}{l}\text { "Work without Hope" line } 11 \text { in } P W \\
\text { (1912) 1:447 }\end{array}$ \\
\hline uncounteracted & 1818 & Friend $(C C) 1: 517$ \\
\hline uncumbrous & 1800 & Letters (1956) 1:577 \\
\hline undeliberateness & 1817 & Biographia (CC) 2:56 \\
\hline under-consciousness & 1816 & Lay Serm (CC) 80 \\
\hline undermarked & 1808 & Letters (1956) 3:150 \\
\hline underpain & 1817 & Biographia (CC) $2: 234$ \\
\hline understrain & 1802 & $\begin{array}{l}\text { “Happy Husband" line } 22 \text { in } P W(1912) \\
1: 388\end{array}$ \\
\hline undetained & 1795 & "Eolian Harp" line 39 in $P W(1912) 1: 101$ \\
\hline
\end{tabular}




\begin{tabular}{|c|c|c|}
\hline undiverging & 1795 & Letters (1956) 1:165 \\
\hline undivorceable & 1825 & $A R(1848) 1: 205$ \\
\hline undropped & 1798 & "Nightingale" line 104 in $P W(1912) 1: 267$ \\
\hline unfanatical & $1824-26$ & Marginalia $(C C) 2: 1167$ \\
\hline unfascinate & 1825 & $A R(1848) 1: 288$ \\
\hline unfoodful & 1816 & Lay Serm $(C C) 43$ \\
\hline ungauntleted & 1800 & $\begin{array}{l}\text { "Tallyrand to Lord Grenville" line } 12 \text { in } \\
P W(1912) 1: 341\end{array}$ \\
\hline Unicist & 1807 & Marginalia (CC) 2:799; $1832 T T(C C) 2: 161$ \\
\hline unillumed & 1796 & $\begin{array}{l}\text { Destiny of Nations line } 166 \text { in } P W(1912) \\
\text { 1:137 }\end{array}$ \\
\hline unimpinging & 1800 & Letters $(1956) 1: 571$ \\
\hline unindividual & 1812 & Lit Rem 1:351 \\
\hline uninfluencive & 1816 & Lay Serm (CC) 95 \\
\hline uninheritability & 1812 & Lit Rem 1:322 \\
\hline uninjurious & 1809 & Friend (CC) 2:142 \\
\hline unintroitive & 1818 & Lects on Lit (CC) $2: 306$ \\
\hline unipersonal & 1810 & Lit Rem 3:220; 1817 Lay Serm (CC) 182n \\
\hline uniqueness & 1820 & Letters (1956) 5:26 (Neumann) \\
\hline unmaddened & 1797 & Osorio 3.22 in $P W(1912) 2: 551$ \\
\hline unmethodizing & 1818 & Encycl Metrop (1845) 1:4, introduction \\
\hline unmodifiable & 1825 & Lit Rem $2: 353$ \\
\hline unmotived & 1794 & Letters $(1956) 1: 63$ \\
\hline unobeying & 1796 & $\begin{array}{l}\text { "Destiny of Nations" line } 66 \text { in } P W(1912) \\
1: 133\end{array}$ \\
\hline unparticipating & 1795 & Letters (1956) 1:171 \\
\hline unpossessedness & 1818 & Lects on Lit (CC) 2:306 \\
\hline unprecludible & 1825 & Letters (1956) 5:429 \\
\hline unprejudice & 1800 & Let. in Sotheby's Catalogue (1899) \\
\hline unprotrusive & 1825 & $A R(1848) 1: 148 \mathrm{n}$ \\
\hline unprovisioned & 1796 & Letters (1956) 1:273 \\
\hline unpublishable & 1815 & Letters (1956) 4:572 \\
\hline unrecognizable & 1817 & Biographia (CC) 2:79 \\
\hline unrefracting & 1827 & Lit Rem $4: 408$ \\
\hline unsaluting & 1795 & Letters (1956) 1:168 \\
\hline un-scarified & 1818 & Lects on Lit (CC) $2: 306$ \\
\hline unsealed & 1800 & Piccolom 1.11 .105 in $P W(1912) 2: 630$ \\
\hline un-Shakspearian & a 1834 & Lit Rem 2:115 \\
\hline unstiffening & 1832 & Letters (1956) 6:901 \\
\hline unsubstantiate & 1799 & Letters (1956) 1:479 \\
\hline unsympathizability & 1818 & Lects on Lit (CC) $2: 176$ \\
\hline untheoretic & 1809 & Friend $(C C) 1: 85$ \\
\hline unwaning & 1807 & $\begin{array}{l}\text { "To Wordsworth" line } 41 \text { in } P W(1912) \\
1: 406\end{array}$ \\
\hline unwithholding & 1810 & Lit Rem $3: 243$ \\
\hline up-blew & 1798 & $\begin{array}{l}\text { Ancient Mariner line } 336 \text { in } P W(1912) \\
\quad 1: 200\end{array}$ \\
\hline
\end{tabular}




\begin{tabular}{|c|c|c|}
\hline upboiling & 1794 & Fall of Robespierre 1.88 in $P W(1912) 2: 498$ \\
\hline upbuoyance & $? 1799$ & "Visit of Gods" line 13 in $P W(1912) 1: 310$ \\
\hline up-thundering & 1796 & $\begin{array}{l}\text { "Ode Departing Year" line } 142 \text { in } P W \\
\text { (1912) } 1: 168\end{array}$ \\
\hline uptrilled & 1799 & $\begin{array}{l}\text { "Lines in Concert-room" line } 7 \text { in } P W \\
\text { (1912) } 1: 324\end{array}$ \\
\hline upworking & 1819 & Lects on Lit $(C C) 2: 351$ \\
\hline uterifaction & 1819 & Notebooks $4: 4512 ;$ not in $O E D$ \\
\hline utterancy & 1827 & "Improvisatore" in $P W(1912) 1: 464$ \\
\hline vaccimulgence & 1796 & Letters (1956) 1:251 (Neumann) \\
\hline vegetivorous & 1822 & Notebooks 4:4880; not in $O E D$ \\
\hline verbarian & 1830 & $C \mathcal{E S} S(C C) 24 \mathrm{n}$ \\
\hline veridictions & 1821 & Notebooks 4:4809; not in $O E D$ \\
\hline visual image & 1810 & $\begin{array}{l}\text { Lit Rem } 3: 295 ; 1817 \text { Biographia (CC) 1:72n } \\
\quad \text { (Hall) }\end{array}$ \\
\hline visualized & 1817 & Biographia $(C C) 1: 47 \mathrm{n}$ \\
\hline vital interests & 1810 & Friend $(C G) 2: 300$ \\
\hline vital-philosophy & 1817 & Biographia (CG) 1:247; not in $O E D$ (Hall) \\
\hline vitific & 1819 & Notebooks 4:4553; not in $O E D$ \\
\hline Walkerite & 1830 & $T T(C G) 1: 116$ \\
\hline warmthless & $? 1825-26$ & $\begin{array}{l}\text { "The Pang More Sharp" line } 3 \text { in } P W \\
\text { (1912) 1:457 }\end{array}$ \\
\hline whirl-brain & 1817 & Biographia $(C C) 1: 189$ \\
\hline wishless & 1819 & Letters (1956) 4:967 \\
\hline worshipability & 1812 & Lit Rem 1:378 \\
\hline wreathless & 1825 & $\begin{array}{l}\text { "Work without Hope" line } 11 \text { in } P W \\
\text { (1912) } 1: 447\end{array}$ \\
\hline year-long & 1813 & Letters (1956) 3:437 \\
\hline yester-afternoon & 1806 & Letters (1956) 2:1174 \\
\hline zanyism & 1818 & Lit Rem 1:138 \\
\hline zincify & 1801 & Letters (1956) 2:726 \\
\hline zoic & 1819 & $\begin{array}{l}\text { Notebooks } 4: 4617,4: 4862 \text {; antedates } O E D \\
\quad[1863]\end{array}$ \\
\hline zoo-organic & 1821 & Letters (1956) 5:137 \\
\hline zoophobia & 1819 & Notebooks 4:4566; antedates OED [1901] \\
\hline zoo-physical & 1820 & $\begin{array}{l}\text { Life of Wesley (1846) 2:82; antedates OED } \\
\text { [no citations] (McKusick) }\end{array}$ \\
\hline
\end{tabular}

